Assurances et gestion des risques

Insurance and Risk Management

\title{
Are Counterparty Arrangements in Reinsurance a Threat to Financial Stability?
}

\author{
Matt Davison, Darrell Leadbetter, Bin Lu et Jane Voll
}

Volume 86, numéro 2-3, décembre 2019

URI : https://id.erudit.org/iderudit/1068506ar

DOI : https://doi.org/10.7202/1068506ar

\section{Aller au sommaire du numéro}

\section{Éditeur(s)}

Faculté des sciences de l'administration, Université Laval

\section{ISSN}

1705-7299 (imprimé)

2371-4913 (numérique)

Découvrir la revue

\section{Citer cet article}

Davison, M., Leadbetter, D., Lu, B. \& Voll, J. (2019). Are Counterparty Arrangements in Reinsurance a Threat to Financial Stability? Assurances et gestion des risques / Insurance and Risk Management, 86(2-3), 191-234. https://doi.org/10.7202/1068506ar

\section{Résumé de l'article}

L'interdépendance entre assureurs et réassureurs à l'échelle mondiale n'est pas bien comprise, peut présenter un risque important pour le secteur et avoir des incidences macroéconomiques. Les modèles des relations complexes qui existent entre les réassureurs et d'autres acteurs du système financier et de l'économie réelle en sont aux balbutiements. Des segments du marché demeurent opaques pour les autorités de réglementation et les participants. C'est en particulier le cas des accords de contrepartie qui, chez les réassureurs, prennent la forme de contrats de rétrocession. Pour modéliser ces relations complexes, les auteurs créent plusieurs réseaux plausibles, chacun étant cohérent avec les données des états financiers des réassureurs. Ces réseaux sont soumis à des tests de résistance fondés sur des scénarios de pertes extrêmes mais vraisemblables. L'apport de cette analyse au corps de travaux existants est triple : a) elle applique à l'industrie de l'assurance la méthode des modèles de réseau communément utilisée dans les recherches sur le secteur bancaire ; b) elle évalue la présence de liens croisés entre réassureurs non à l'aide des primes mais des réclamations potentielles ; c) l'attention est portée sur le segment le plus opaque du marché mondial de l'assurance, à savoir les accords de contrepartie entre réassureurs internationaux (rétrocession). Les auteurs font deux constats : la contagion est plausible au sein du marché mondial de la réassurance, et l'ampleur des pertes en cas de perturbation dépend a) de la distribution des risques parmi les contreparties ; b) de l'événement déclencheur de difficultés financières ; c) du délai de règlement des réclamations et d) du degré de compensation multilatérale des expositions. Ces constats tendent à montrer qu'une étude approfondie des pratiques sectorielles dans ces quatre domaines permettrait d'améliorer l'évaluation des risques dans le secteur de l'assurance et de favoriser la stabilité financière.
Tous droits réservés $\odot$ Faculté des sciences de l'administration, Université Laval, 2020
Ce document est protégé par la loi sur le droit d'auteur. L'utilisation des services d’Érudit (y compris la reproduction) est assujettie à sa politique d'utilisation que vous pouvez consulter en ligne.

https://apropos.erudit.org/fr/usagers/politique-dutilisation/ 


\section{ARE COUNTERPARTY ARRANGEMENTS IN REINSURANCE A THREAT TO FINANCIAL STABILITY? ${ }^{1}$}

Matt DAVISON, ${ }^{2}$ Darrell LEADBETTER, ${ }^{3}$ Bin LU4 and Jane VOLL ${ }^{5}$

\section{ABSTRACT}

Interconnectedness among insurers and reinsurers at a global level is not well understood and may pose a significant risk to the sector, with implications for the macroeconomy. Models of the complex interactions among reinsurers and with other participants in the financial system and the real economy are at a very early stage of development. Parts of the market remain opaque to both regulators and market participants, particularly the counterparty arrangements among reinsurers through retrocession agreements. The authors create several plausible networks to model these relationships, each consistent with the financial statement data of the reinsurer. These networks are stress-tested under a series of severe but plausible catastrophic-loss scenarios. This analysis contributes to the literature by (i) applying a network-model approach common in the banking literature to the insurance industry; (ii) assessing the interconnections among reinsurers through potential claims rather than premiums; and (iii) investigating the most opaque part of the global insurance market, namely, counterparty arrangements among global reinsurers (retrocession). The authors find that contagion in the global reinsurance market is plausible and that the size of the potential market disruption is sensitive to (i) the distribution of risk among counterparties, (ii) the trigger for financial distress, (iii) the time horizon for claims resolution and (iv) the degree of loss netting. The findings suggest that further study of industry practices in these four areas would improve our ability to assess risk in the insurance sector and promote financial stability.

JEL classification: G10, G15, G18, G22, G28, C63

Keywords: Bank classification: Financial stability; Financial system regulation and policies; Financial institutions; Financial services 
L'interdépendance entre assureurs et réassureurs à l'échelle mondiale n'est pas bien comprise, peut présenter un risque important pour le secteur et avoir des incidences macroéconomiques. Les modèles des relations complexes qui existent entre les réassureurs et d'autres acteurs du système financier et de l'économie réelle en sont aux balbutiements. Des segments du marché demeurent opaques pour les autorités de réglementation et les participants. C'est en particulier le cas des accords de contrepartie qui, chez les réassureurs, prennent la forme de contrats de rétrocession. Pour modéliser ces relations complexes, les auteurs créent plusieurs réseaux plausibles, chacun étant cohérent avec les données des états financiers des réassureurs. Ces réseaux sont soumis à des tests de résistance fondés sur des scénarios de pertes extrêmes mais vraisemblables. L'apport de cette analyse au corps de travaux existants est triple: a) elle applique à l'industrie de l'assurance la méthode des modèles de réseau communément utilisée dans les recherches sur le secteur bancaire; b) elle évalue la présence de liens croisés entre réassureurs non à l'aide des primes mais des réclamations potentielles; c) l'attention est portée sur le segment le plus opaque du marché mondial de l'assurance, à savoir les accords de contrepartie entre réassureurs internationaux (rétrocession). Les auteurs font deux constats: la contagion est plausible au sein du marché mondial de la réassurance, et l'ampleur des pertes en cas de perturbation dépend a) de la distribution des risques parmi les contreparties; b) de l'événement déclencheur de difficultés financières; c) du délai de règlement des réclamations et d) du degré de compensation multilatérale des expositions. Ces constats tendent à montrer qu'une étude approfondie des pratiques sectorielles dans ces quatre domaines permettrait d'améliorer l'évaluation des risques dans le secteur de l'assurance et de favoriser la stabilité financière.

Classification JEL: G10, G15, G18, G22, G28, C63

Mots-clés: Classification de la Banque: Stabilité financière; Réglementation et politiques relatives au système financier; Institutions financières; Services financiers

\section{NON-TECHNICAL SUMMARY}

Reinsurance is insurance for insurers and is an important risk- and capital-management tool for the insurance industry. Through reinsurance, risk exposure is transferred from domestic markets to international reinsurers. Disruptions in the reinsurance market have historically been linked to crises in the primary insurance industry as capacity becomes constrained. Retrocession involves risk sharing among reinsurers and is an important source of off-balance-sheet capital. The reinsurance and retrocession market is a complicated network of institutions exchanging their risk exposures in order for each institution to 
achieve a desired risk profile. In a perfect information environment, reinsurers would fully understand their interconnections and exposure within the global reinsurance market.

However, an important feature of the retrocession market is its opacity, providing market participants (regulators and reinsurers) with a line of sight to only a portion of the total market. Reinsurers generally have detailed information on their direct counterparty but not necessarily on their counterparty's retrocession arrangements. This exchange of risk has the potential to result in a transfer of exposures to the same set of players. A reinsurance spiral can occur when reinsurers extensively underwrite each other's risk exposures, possibly resulting in the circulation of exposures among the same set of players.

Reinsurance spirals are rare but have the potential to disrupt insurance markets and ultimately real economic sectors as insurance becomes either unaffordable or its availability becomes restricted. It is therefore important to assess the resilience of the reinsurance market through financial stress testing. Given the opacity of a market where the size and connections of the network are not known, we test several plausible networks based on the financial statement data of a sample of reinsurers. These networks were then placed under stress through very severe but plausible catastrophic loss scenarios.

Applying a network model approach, common in the banking stability literature, to the reinsurance industry setting, our results suggest that while the reinsurance market may be resilient to very large catastrophic shocks, this resilience is sensitive to the structure of the network and features of the reinsurance contract such as loss netting.

\section{INTRODUCTION}

The reinsurance market is a relatively small market compared with the insurance industry. Its capitalization, all lines of business included, was estimated at the end of 2014 to be US $\$ 575$ billion (Aon Benfield 2015a). Nevertheless, reinsurance, often described as insurance for insurance companies, is a critical part of most national insurance industries. Disruptions in the reinsurance market have been linked to primary insurance industry crises, with implications for the real economy (Berger, Cummins and Tennyson 1992). ${ }^{6}$ 
In the aftermath of the financial crisis of 2007-09, a number of studies have explored the stability of the insurance and reinsurance industries, particularly from the vantage point of identifying the potential for systemic risk (IAIS 2012; Geneva Association 2010; Group of Thirty 2006). To date, this work has resulted in the identification of some globally systemically important insurers, with the identification of systemically important reinsurers planned for the future as an ongoing exercise.

Neither academic nor policy-focused analyses of the insurance and reinsurance sector have tended to explicitly consider the role of retrocession - the counterparty arrangements for risk sharing among reinsurers, and an important form of off-balance-sheet capital (Shiu 2011). ${ }^{7}$ An important feature of the retrocession market is its opacity to both market participants and regulators. In general, parties to a retrocession contract will have information about the nature of the risk that the ceding reinsurer is looking to offload or "place" and, if syndicated, the names of other participating reinsurers. Parties typically do not have full information about the nature and extent of counterparties' exposures to other reinsurers and other losses. In this context, it is possible for contagion or a reinsurance spiral (Bain 1999) to occur, in which the losses of one party cascade to others in the network.

Cascades of failures have occasionally torn through the reinsurance community. For example, between 1987 and 1990, the so-called "London Market Spiral" led to significant losses in the London reinsurance market. The chronology of these events is described in Bain (1999), and their impact on the US property and liability insurance industry is related in Fields, Klein and Myskowski (1998). This spiral was rooted in major catastrophes, including the destruction of the Piper Alpha Oil platform in the North Sea in 1988 in an industrial accident, the North European windstorms in 1987, the San Francisco earthquake, Hurricane Hugo, and the Exxon Valdez oil disaster (the last three in 1989). However, the impact of these disasters was magnified by the financial relationships among reinsurance entities. (For more information, see Appendix 1.)

This paper aims to begin to address this shortfall in the literature by investigating the features of the retrocession market that would need to be in place for contagion to be likely and to examine the dimensions of the potential losses that could ensue. We do this by developing a series of network models of the potential relationships among reinsurers and stress-testing these relationships by subjecting the networks to a series of plausible catastrophic loss shocks. 
The property and casualty $(\mathrm{P} \& \mathrm{C})$ industry does not accumulate large reserves relative to the size of the underlying policy exposures. This is because most $\mathrm{P} \& \mathrm{C}$ contracts are written over short terms and reserves are established to cover expected probabilities and severities. Unexpected large claim events are managed through capital reserves or through the purchase of reinsurance. Premiums accumulated in one year are largely either used, or earned as profit, in that same year. It should be noted that, in the life insurance business with its long-lived whole life and annuity business lines, the reserve situation is quite different. With the reliance on reinsurance for large unexpected events, problems in the reinsurance market can soon feed back into the primary insurance market and, hence, to the broader economy.

This paper is organized as follows. Section 2 reviews the literature; Section 3 motivates the study; and Section 4 describes our data. Section 5 outlines the network concepts and model employed in the analysis. Section 6 reports the results, discusses the findings and offers some suggestions for further research. Section 7 concludes.

\section{LITERATURE REVIEW}

In recent years, a growing body of research has investigated the economic impact and the financial stability implications of reinsurance, including retrocession. The International Association of Insurance Supervisors (IAIS) concludes that reinsurance is unlikely to contribute to or amplify systemic risk (IAIS 2012). This is similar to the conclusions of the Geneva Association (2010). The conclusions are based on the relatively small size of premiums ceded and retroceded relative to the primary insurance market. In addition, the IAIS noted that reinsurance had only been a factor in less than 4 per cent of insurance company failures (IAIS 2012). ${ }^{8}$ Grace (2010) and Harrington (2009) find there may be instances of systemic risk (specifically AIG) but that generally insurance does not present a source of systemic risk.

Bibas, Stéphane and Lemoyne de Forges (2011) note that, even if capital depletion of reinsurers does not lead to higher default risk, it will have important implications for reinsurance prices and underwriting capacity. Their model indicates that a series of smaller losses may have a deeper impact on reinsurance pricing and capacity constraints than a single large loss. Cummins and Weiss (2011) and Acharya et al. (2009) argue that the property and casualty industry may be subject to systemic risk because of the complexity and opacity of the 
reinsurance market. Kampman, Lelyveld and Liedorp (2011) found no systemic implications for the Dutch insurance industry from the failure of the reinsurance industry. However, their analysis focused on credit risks to the local Dutch market and, due to information gaps, did not consider interconnections through retrocession or cross-participation, noting "there is very little information on the ultimate location of risks. It may not be clear who bears the final risk, a situation very much akin to the securitized loans market."

Park and Xie (2014) investigate the implications around the use of rating triggers for managing counterparty risk by insurers in the industry and find evidence of close interconnectedness between primary insurers and reinsurers.

\section{Motivation}

Although traditional insurance activities may not be considered globally systemically important in general (IAIS 2012); Geneva Association 2010), there have been several instances of insurance market crises becoming important macroeconomically, with implications for fiscal and monetary policy (Dahlen, Peter and Saxena 2012). (See Appendix 1 for some examples.) In addition, disruptions in reinsurance markets have been shown to play an important role in primary insurance market crises (Berger, Cummins and Tennyson 1992). Billio et al. (2012) find, using principal component analysis and Granger-causality tests, statistically significant interconnections among insurers and other financial service institutions (banks, brokers and hedge funds). They also find that these interconnections have grown between their sample periods of 1994-96 and 2006-08.

Financial disasters are often attributed to leverage. The impact of margin calls looms large in popular accounts of the 1929 market crash (Galbraith and Galbraith 2009), and it is the huge leverage associated with financial derivatives that led Warren Buffet to name them "weapons of mass [financial] destruction." "However, leverage is a slippery concept when it comes to reinsurance, or even insurance. For instance, if a company provides fire insurance on one thousand $\$ 500,000$ houses randomly distributed across a region, one measure of the total possible loss is $\$ 0.5$ billion. Such a small company might take in only about $\$ 1$ million in premiums each year against this potential loss and have reserves in the millions against the losses, for an apparently huge leverage. However, the chances that all the homes in this sample insurer's 
portfolio would be destroyed in any given year are very low. For this reason, insurers consider actuarial measures such as probable maximum loss (PML) that, in this example, would lead to much less exposure and so much less leverage. Unfortunately, these actuarial measures are rarely quoted in financial statements. The concern that some of the benefits of diversification may be lost through complicated and partially unknown reinsurance treaties helps motivate the present work.

While there have been studies of the stability of the reinsurance marketplace, to date none have examined the additional risk that may stem from counterparty relationships among reinsurers through retrocession. Depending on how these relationships are structured, they could amplify losses following a major claims event and potentially destabilize the primary insurance sector, with implications for the real economy.

In this paper, we proceed by working to find and quantify scenarios under which another reinsurance crisis might emerge. Our specific scenario starts with a number of large P\&C disasters, the cost of which is shared between the primary and the reinsurance industries. The cost of these disasters is one aspect of the stress scenario. Next, we distribute the reinsurance portion of these losses among various reinsurers according to various heuristics to see the financial statement impact. Under various assumptions both about when financial statement stress leads to company failure and on the impact of these failures on other corporate relationships, we assess how many reinsurers fail as well as the fraction of total reinsurer assets and equity that, in consequence, leaves the market. Our model depends on a number of assumptions about market structure and includes some indicative parameters. In the next section, we showcase the data that we are using to cast light on this market.

\section{DATA}

Data for this analysis are compiled from financial statements of global reinsurance groups. Loss scenarios for stress-testing are based on historical data for natural disaster losses.

\subsection{Financial statements}

A data set obtained from consolidated financial statements for 67 large reinsurers was developed using data from annual reports and publicly available regulatory filings. The data set contains information for the 
years 2005 through 2010. All calculations and figures in the paper refer to data drawn from the 2010 year. Generally, though not invariably, year-ends are 31 December. While the companies selected have reinsurance as their primary activity, the consolidated data may include primary insurance figures or even non-insurance information, if the reinsurer is part of a group that also includes those businesses. The reinsurance groups may also contain multiple legal entities that may cede risk to one another for tax or other business reasons; in the absence of information to this effect, and given that the data are on a consolidated basis, we assume for the purposes of the model that each group is a single monolithic entity that trades only with entities outside the group. While it would have been cleaner to work with a world in which each reinsurance company confines its activities to reinsurance alone, our modelling framework is resilient to the fact that some reinsurers are a consolidated part of a larger group. Our model distributes losses related to metrics of reinsurance activity and charges them to the balance sheet of the entire group. To the extent that losses in one part of the business are covered by the balance sheet of the whole business, this is reasonable. A small bias might exist in the case where the reinsurer is in a group with primary insurance businesses, and where the primary insurer also retains some significant portion of a catastrophe loss that our framework does not model as an additional claim on the assets of the consolidated group.

For each company we have at the very least income statement information about direct premiums written, reinsurance assumed, reinsurance ceded and claims paid. We also have balance sheet information for total assets, total liabilities and equity. In most cases, we have very detailed breakdowns about both assets and liabilities. With assets in particular, it is generally possible to determine the amount allocated to marketable securities (cash, money market, bonds and equities) as well as to less-liquid securities. Table 1 contains summary information on the data set.

The total invested assets for 2010 are about US $\$ 2.6$ trillion-much larger than the total 2010 invested assets of US $\$ 747$ billion reported by IAIS (2010). This is because some of the accounts in our sample come from consolidated groups with a large amount of activity both in reinsurance and in other industries.

The reinsurers in the data set are distributed across multiple regions. Table 2 gives a sense of the relative sizes of the reinsurers operating in these regions in our data set. 


\begin{tabular}{|c|c|c|c|c|c|c|c|c|c|c|c|c|c|c|c|}
\hline \multicolumn{4}{|c|}{$\begin{array}{l}\text { DIRECT PREMIUMS } \\
\text { WRITTEN (DPW) }\end{array}$} & \multicolumn{3}{|c|}{ REINSURANCE ASSUMED (RA) } & \multicolumn{3}{|c|}{ REINSURANCE CEDED } & \multicolumn{6}{|c|}{ TOTAL SAMPLE } \\
\hline Year & P\&C & L\&H & Total & P\&C & L\&H & Total & P\&C & L\&H & Total & PW & Claims & $\begin{array}{l}\text { L\&H } \\
\text { Bens. }\end{array}$ & Assets & Liab. & Equity \\
\hline 2010 & $\$ 204$ & $\$ 146$ & $\$ 500$ & $\$ 55$ & $\$ 25$ & $\$ 117$ & $-\$ 36$ & $-\$ 14$ & $-\$ 63$ & $\$ 537$ & $-\$ 291$ & $-\$ 107$ & $\$ 3,880$ & $\$ 3,032$ & $\$ 848$ \\
\hline 2009 & $\$ 164$ & $\$ 153$ & $\$ 391$ & $\$ 53$ & $\$ 21$ & $\$ 113$ & $-\$ 26$ & $-\$ 10$ & $-\$ 49$ & $\$ 438$ & $-\$ 237$ & $-\$ 105$ & $\$ 3,083$ & $\$ 2,378$ & $\$ 706$ \\
\hline 2008 & $\$ 209$ & $\$ 145$ & $\$ 412$ & $\$ 60$ & $\$ 22$ & $\$ 96$ & $-\$ 37$ & $-\$ 8$ & $-\$ 57$ & $\$ 440$ & $-\$ 270$ & $-\$ 84$ & $\$ 3,628$ & $\$ 2,786$ & $\$ 843$ \\
\hline 2007 & $\$ 205$ & $\$ 116$ & $\$ 401$ & $\$ 63$ & $\$ 23$ & $\$ 99$ & $-\$ 32$ & $-\$ 9$ & $-\$ 58$ & $\$ 429$ & $-\$ 277$ & $-\$ 100$ & $\$ 4,016$ & $\$ 3,084$ & $\$ 932$ \\
\hline 2006 & $\$ 162$ & $\$ 55$ & $\$ 350$ & $\$ 37$ & $\$ 9$ & $\$ 62$ & $-\$ 29$ & $-\$ 7$ & $-\$ 56$ & $\$ 342$ & $-\$ 240$ & $-\$ 40$ & $\$ 4,593$ & $\$ 2,448$ & $\$ 2,145$ \\
\hline 2005 & $\$ 152$ & $\$ 57$ & $\$ 391$ & $\$ 25$ & $\$ 8$ & $\$ 45$ & $-\$ 26$ & $-\$ 4$ & $-\$ 67$ & $\$ 356$ & $-\$ 278$ & $-\$ 42$ & $\$ 3,332$ & $\$ 2,366$ & $\$ 966$ \\
\hline
\end{tabular}

* We draw the reader's attention to the large increase in equity from 2005 to 2006 followed by a large decrease from 2006 to 2007 . Hurricane Katrina occurred in 2005 and, after a large disaster like this, reinsurance rates rise, attracting much new capital to the market.

Sources: Insurer financial statements, 2005-10, as assembled. All figures in US\$ billions 
TABLE 2 Geographical Distribution of Sample Data (based on head office location)

\begin{tabular}{|c|c|c|c|c|c|}
\hline & $\begin{array}{l}\text { NUMBER } \\
\text { OF GROUPS }\end{array}$ & $\begin{array}{l}\text { REINSURANCE } \\
\text { CEDED } \\
\text { (US\$ BILLIONS) }\end{array}$ & $\begin{array}{c}\text { EQUITY } \\
\text { (US\$ BILLIONS) }\end{array}$ & $\begin{array}{c}\% \\
\text { REINSURANCE } \\
\text { CEDED }\end{array}$ & \% EQUITY \\
\hline Africa & 1 & 0.053 & 0.344 & 0.08 & 0.04 \\
\hline Asia & 9 & 6.040 & 92.900 & 9.61 & 10.95 \\
\hline ANZ & 1 & 2.070 & 10.393 & 3.29 & 1.23 \\
\hline Europe & 18 & 20.212 & 257.039 & 32.15 & 30.31 \\
\hline N America & 17 & 21.125 & 387.915 & 33.61 & 45.74 \\
\hline Bermuda & 21 & 13.600 & 99.465 & 21.25 & 11.73 \\
\hline Total & 67 & 62.861 & 848.055 & 100.00 & 100.00 \\
\hline
\end{tabular}

Source: Authors' calculations from the data set

Full sets of financial statements for each of these insurance groups, including the amounts retroceded to non-affiliated counterparties, were used in this study. However, the financial statements neither provide information on the names of those counterparties nor describe the nature of the interconnections with those counterparties.

Therefore, while the data collected from financial statements can be used to identify the quantity of overall risk assumed/retroceded, they do not provide information on the interconnections among specific market participants. To gauge the degree of plausible risk that may reside in the network of relationships, we simulate a series of events under different assumptions of those relationships to test the robustness of the network.

\subsection{Insured losses}

In addition to reinsurer financial information, data on global catastrophe losses were used to serve as a reference for calibrating the model simulations. Munich Re's NatCat Service highlights the increasing severity of insured and uninsured catastrophe losses. Data of losses from individual events from the Centre for Research on the Epidemiology of Disasters indicate that, during the period 2000 to 2013, most events remain relatively small with an average event loss of US $\$ 1.7$ billion and, signifying a highly skewed distribution, a median event loss of US $\$ 200$ million. Very large loss events remain rare, with only four events with losses greater than US $\$ 50$ billion occurring over the period. 
However, two of these (Hurricane Katrina in 2005 and the Tohoku earthquake in Japan in 2011) were over US $\$ 100$ billion, highlighting the potential for very large tail events.

We take the expected annual insured losses of the global P\&C insurance market as one of the system inputs in the model. Expected annual catastrophic losses are shared among primary insurers and reinsurers. Charts describing historical catastrophic loss data are found in Appendix 2.

\section{THE MOdEL}

Our mathematical model is based on the network model of Sheldon and Maurer (1998); Upper and Worms (2004); and Kampman, Lelyveld and Liedorp (2011). The network model is motivated by the banking system where links are given by the size of the market exposure between counterparties. Similar links also exist in the reinsurance and retrocession market. A link is established between a primary insurer and a reinsurer when the primary insurer purchases reinsurance contract(s) from the reinsurer. Similarly, a link is established between two reinsurers/retrocessionaires when one cedes risks to the other. In neither case is the size of the exposure known.

Instead of trying to quantify the size of the exposure between two counterparties in the reinsurance market or retrocession market, we concentrate on the actual payments made between counterparties when an extreme event happens. This leads us to consider the losses suffered by each individual company, not just the risk exposure.

We fit Pareto distributions to historical data on worldwide insurance losses as summarized in Appendix 2. The shape distribution fit to the Pareto Distribution is 1.5229 . Each time, we randomly draw a number from the distribution and then multiply it with a user-set magnitude level $\left(10^{8}, 10^{9}, 10^{10}\right)$ to simulate the expected loss.

To model the fact that the size of our disasters is fitted to historical disaster-cost data but that a bad year such as 1989 might bring several disasters, we assume a plausible bad year with 10 disasters. However, our model does not consider the intra-year time structure; it is as if all these disasters were paid at a single point in the year. Phrased another way, we model losses as coming from the sum of 10 iid Pareto distributions. Based on the fact that disasters must be booked in the year in which they occur, this assumption is fairly realistic. ${ }^{10}$ 
These disasters lead to claims from primary insurers, some fraction (denoted by $\mathrm{RL}_{1}$ ) of which pass through to the reinsurers. We must then decide how to attribute them to the individual reinsurers in our model. Exactly how this is done will be discussed later. Once losses are at the reinsurer level, a certain fraction (denoted by $\mathrm{RL}_{2}$ ) is passed on to the retrocession market. The participants in the retrocession market are identical to the participants in the reinsurance market, so this represents a second source of loss distribution, called the second-stage loss.

Although catastrophe bonds, and other types of insurance-linked securities (ILSs) such as swaps, sidecars, etc., have been much touted in recent years (Aon Benfield 2015b), their impact on the retrocession market remains non-determinative. Aon Benfield (2015a) estimates that the capital of the reinsurance market was US $\$ 575$ billion as at the 2014 year-end. This $\$ 575$ billion of capital included $\$ 62$ billion of other ILS such as swaps and sidecars. The same Aon Benfield report states that the total capital of catastrophe bonds was $\$ 24$ billion, or just 4.1 per cent of the total reinsurance capital. While this is enough to have an impact on reinsurance pricing in the higher layers of covered perils, it is not very material for the scenarios examined here, scenarios that investigate the impact of catastrophic losses on the stability of the reinsurance market.

To estimate $\mathrm{RL}_{1}$, we consider Table 3 , which gives the size of recent losses and the fraction borne by reinsurers. These data suggest that a choice of $\mathrm{RL}_{1}=50$ per cent, as made here, is reasonable. Obtaining estimates for $\mathrm{RL}_{2}$ is harder, but we also take 50 per cent. Note that these numbers are also broadly consistent with figures presented in Dahlen and Peter (2012).

\subsection{The reinsurance and retrocession network}

Figure 1 illustrates how losses are distributed and redistributed among participants in the reinsurance and retrocession market. Financial losses caused by the catastrophic event directly hit the insured individuals or companies, who make claims to their primary insurers. The level of insured losses depends on multiple factors, such as the catastrophes' location and physical type, the insurance penetration ratio in the region, etc. For example, Dahlen and Peter (2012) show that losses due to earthquakes (geophysical events) have been less insured on average than those from storms (meteorological events). A comparison of the total losses and insured losses for most expensive natural disasters in 2011 can be found on Statista's website (Statista 2014). 
TABLE 3 Recent Disaster Losses with Insured Losses and Reinsurer Share

\begin{tabular}{|c|c|c|c|c|c|}
\hline EVENT & LOCATION & DATE & $\begin{array}{c}\text { INSURED } \\
\text { LOSS } \\
\text { (US\$ BILLION) }\end{array}$ & $\begin{array}{l}\text { REINSURER } \\
\text { SHARE }\end{array}$ & $\begin{array}{l}\text { REINSURER } \\
\text { FRACTION (\%) }\end{array}$ \\
\hline Earthquake/Tsunami & Japan & March 2011 & 37.5 & 15 & 40 \\
\hline Earthquake & New Zealand & Feb 2011 & 13 & 9.5 & 73 \\
\hline Flood & Thailand & Nov 2011 & 10 & 6 & 60 \\
\hline Earthquake & Chile & Feb 2010 & 8.3 & 7.9 & 95 \\
\hline Flood & Australia & Jan 2011 & 5 & 2.2 & 44 \\
\hline Hurricane Katrina & United States & Aug 2005 & 47.6 & 22.5 & 47 \\
\hline Hurricane Sandy & United States & Nov 2012 & 18.8 & 8.5 & 45 \\
\hline Total & & & 140.2 & 71.6 & 51 \\
\hline
\end{tabular}

Source: Data from the Insurance Information Institute

FIGURE 1 Process of Losses Distributed/Redistributed in the Reinsurance and Retrocession Market

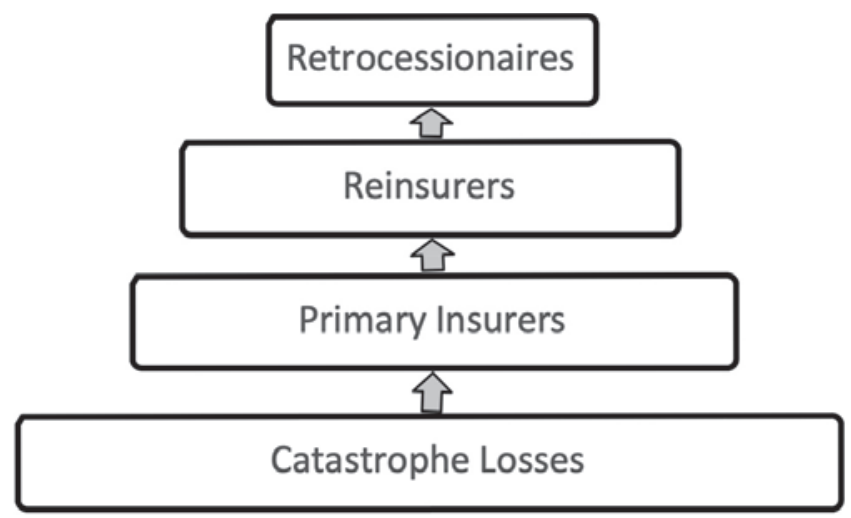

A portion of the losses are now distributed to the primary insurers. In the case of larger losses, the total claims levied on the primary insurer are likely to exceed the pre-determined retention levels of the primary insurer and trigger coverage that had been previously purchased from reinsurers. At this stage, a fraction of the insured losses are distributed to the reinsurers. The portion of the losses that can be recovered by insurers' reinsurers depends on multiple factors but, historically speaking, reinsurers will usually bear 55 to 65 per cent of insured losses when a large natural disaster occurs (Dahlen and Peter 2012). 
Reinsurance companies that have retroceded a share of their exposure in turn report the relevant losses to their retrocessionaires. At this stage, the losses are directed to the retrocession market. In the same fashion, retrocessionaires may seek to retrocede their risks to other reinsurers.

The reinsurance and retrocession network is characterized by a square matrix L. In the square matrix, row and column items represent an aggregate of primary insurers (primary block) and all global reinsurers from our data set. We consider the primary block for the sake of a closed network. By a closed network, we mean that the losses are distributed in the network with none "leaking" out to entities not represented in the market model.

The Matrix L is constructed as illustrated in Table 4. Column P and row $P$ represent aggregate primary insurers (primary block). Column $R_{i}$ and row $R_{i}$ represent reinsurer $i$. The entries $L\left(R_{i}, R_{i}\right)$ are the amount of losses that reinsurer $R_{j}$ recovers from reinsurer $R_{i}$. The entries $L\left(R_{i}, P\right)$ denote the amount of losses that the primary insurance sector recovers from reinsurer $\mathbf{R}_{\mathrm{i}}$.

Since we are working with consolidated data on reinsurance groups, we assume that the reinsurance group does not cede risk to itself. Individual insurers or reinsurers within a corporate group may do so, but these inter-company transactions are netted out for the purposes of this analysis. Thus, all the diagonal cells in matrix $\mathrm{L}$ are 0 , i.e., $\mathrm{L}\left(\mathrm{R}_{\mathrm{i}}, \mathrm{R}_{\mathrm{i}}\right)=0$. We also assume that primaries do not cede to other primaries, but only to reinsurers. Thus the first row of the matrix $\mathrm{L}_{\mathrm{rei}}\left(\mathrm{P}, \mathrm{R}_{\mathrm{i}}\right)=0$.

\section{TABLE 4 The Structure of the Reinsurance and Retrocession Matrix}

\begin{tabular}{ccccc} 
& $\mathrm{COL}$ & & & \\
RoW & $\mathrm{P}$ & $\mathrm{R} 1$ & $\ldots$ & $\mathrm{RN}$ \\
$\mathrm{P}$ & 0 & 0 & $\ldots$ & 0 \\
\hline $\mathrm{R}_{1}$ & $\mathrm{~L}\left(\mathrm{R}_{1}, \mathrm{P}\right)$ & 0 & $\ldots$ & $\mathrm{L}\left(\mathrm{R}_{1}, \mathrm{R}_{\mathrm{n}}\right)$ \\
\hline$\vdots$ & $\ldots$ & $\vdots$ & $\ddots$ & $\vdots$ \\
\hline $\mathrm{R}_{\mathrm{n}}$ & $\mathrm{L}\left(\mathrm{R}_{\mathrm{n}}, \mathrm{P}\right)$ & $\mathrm{L}\left(\mathrm{R}_{\mathrm{n}}, \mathrm{R}_{1}\right)$ & $\cdots$ & 0
\end{tabular}


We use matrices $\mathrm{L}_{\text {rei }}$ and $\mathrm{L}_{\text {ret }}$ to represent the reinsurance and retrocession network accordingly. These two matrices have an identical structure as matrix L, albeit with different numerical values in general. The entries $L_{r e t}\left(R_{i}, P\right)$ are also zeros because primary insurers are assumed not to be involved in the retrocession market.

Note that neither $\mathrm{L}_{\text {rei }}$ nor $\mathrm{L}_{\text {ret }}$ are typically symmetric. We use the convention of reinsurance recoverables in the rows of $\mathrm{L}_{\text {rei }}$ and $\mathrm{L}_{\text {ret }}$. If the matrices are read column-wise, we see the claims that the reinsurers bear. In mathematical terms, $\sum_{j=1}^{N} L\left(R_{i}, R_{j}\right)=L_{i}$ and $\sum_{j=1}^{N} L\left(R_{i}, R_{j}\right)=C_{j}$. $\mathrm{L}_{\mathrm{i}}$ is the liability of the $\mathrm{i}^{\text {th }}$ insurer. $\mathrm{C}_{\mathrm{j}}$ is the claim amount to be recovered from the $j^{\text {th }}$ reinsurer. Apart from the first column, the rest of the matrix $\mathrm{L}_{\mathrm{rei}}$ are zeros since, in this reinsurance network, losses flow from the primary block to reinsurers. In addition, the column $\mathrm{P}$ of the matrix $\mathrm{L}_{\text {ret }}$ must be zero since this matrix represents the retrocession market losses flow from the primary block.

\subsection{Bankruptcy vs. non-bankruptcy}

After the second-stage distribution of losses, we examine the financial health of the reinsurance companies. We do this by comparing their total losses from both reinsurance and retrocession activities with the equity in the company. The retrocession activities are measured on a net basis (claims to be paid are netted against claims made to other counterparties). These claims are measured as a fraction of the corporate equity, taken from the financial statements. We assume that, when claims get too large for a company to pay them, that company must exit the market. We determine this by examining the ratio of claims to equity relative to the user-defined parameter alpha $(\alpha)$. If the claimsto-equity ratio exceeds $\alpha$, the company modelled fails. If a company fails, what happens? We consider two cases. In the first case, which we call "non-bankruptcy," a company pays all its debts, no matter how large, before exiting the industry. In the second, which we term "bankruptcy," the company's ability to pay is examined; in this case, it is possible that not all of the failed insurers' obligations can be repaid, leading to losses for its counterparties.

Naturally $\alpha$ is a difficult parameter to estimate. We use a value of 90 per cent in our calculations, although we investigate the sensitivity of results to this parameter. Referring to Table 5, which provides summary statistics on the types of securities held in the reinsurer's balance sheets, this corresponds to a regulator, in an environment of uncertainty, seeking to act to maximize assets available for a liquidation. 
TABLE 5 Investments on Reinsurer Balance Sheets, 2006-10 (in per cent)

\begin{tabular}{|c|c|c|c|c|c|c|c|}
\hline & 2005 & 2006 & 2007 & 2008 & 2009 & 2010 & AVERAGE \\
\hline Fixed income & 63 & 63 & 58 & 57 & 59 & 57 & 60 \\
\hline Equities & 7 & 8 & 11 & 8 & 8 & 8 & 8 \\
\hline Loans & 11 & 10 & 12 & 15 & 15 & 15 & 13 \\
\hline Real estate & 2 & 1 & 2 & 2 & 2 & 2 & 2 \\
\hline Short-term investments & 3 & 3 & 4 & 4 & 4 & 4 & 4 \\
\hline Other & 14 & 15 & 14 & 15 & 13 & 14 & 14 \\
\hline Total & 100 & 100 & 100 & 100 & 100 & 100 & 101 \\
\hline
\end{tabular}

Source: Our proprietary database

\subsubsection{Non-bankruptcy}

In the first case, non-bankruptcy, we assume that all companies have access to immense credit lines with the net effect that the timings of cash flows are immaterial; this means that the companies fail only when their net losses overwhelm their ability to pay. We assume that even failed companies are still able to pay all their debts no matter how large.

\subsubsection{Bankruptcy}

In a financial liquidity crisis, it may not be as easy to convert the assets of a reinsurer into the cash needed to settle claims (Garcia and Gencay 2007). As a crude model of this, we now suppose that, when claims exceed the fraction $\alpha$ of the reinsurer equity, the company is forced into bankruptcy and retains only a fraction beta $(\beta)$ of its assets. This will often make the firm unable to pay all its claims in full. It is important to note that $\beta=1$ is not equivalent to the non-bankruptcy case, as $\beta=1$ still implies a limit on the amount of payments that the failed entity can make.

Again referring to Table 5, which provides summary statistics on the types of securities held in the reinsurer's balance sheets, we assume that, during times of financial market stress, the assets of the firm can only be sold, even over a fairly long time period, by providing a significant discount. For example, if we believe that about 95 per cent of the value of the fixed income and loans (usually of fairly short duration) may be realized on liquidation, 80 per cent of the value of the 
equities, and 50 per cent of the value of the real estate and other investments, we conclude that a deadweight loss of 10 per cent of assets is easy to imagine in a windup situation. This corresponds to the "stress" $\beta$ of 90 per cent used in the calculations shown later. ${ }^{11}$

The inability to pay claims in full will force companies into bankruptcy, and the impact of these lost claims must be incorporated into the loss/equity ratios of all the failed companies' counterparties. The result may be to drive one or more of these counterparties into bankruptcy as well. It is conceptually possible for this set of model choices to lead to a failure cascade. To model this, we compute an iterative process in which reinsurers are ranked, in terms of claims divided by equity, from weakest to strongest. If the weakest has a claims-to-equity ratio $>\alpha$, it fails and is made bankrupt, losing a fraction (1- $\beta$ ) of its assets in the process. This will often make it impossible for the reinsurer to pay all of its counterparties in full. After paying debt pro rata (in other words, with no regard to seniority), the bankrupt entity is removed from the industry. The remaining reinsurers will now, in general, be in a poorer financial position and so are ranked from weakest to strongest again, until such time as the process leads to a result in which either all companies have a claims/equity ratio $<\alpha$ or all of them have gone bankrupt.

\subsection{Loss distribution}

In the network model setting described above, in order to investigate the financial stress of reinsurers that results from losses transferred from insurers, it is necessary to discover the aggregate loss flowing from the primary block to each reinsurer, as well as the portion of each reinsurer's loss that is borne by their retrocessionaire counterparties and so on. However, in the opaque reinsurance/retrocession marketplace, detailed data on retrocession counterparty arrangements and the risk profile of counterparties to any reinsurer are not readily available. The actual quantity of risk assumed or retroceded between two counterparties is unknown. The opacity of the insurance and reinsurance market makes it impossible to determine precisely the loss distribution and transfer between counterparties.

A variety of ways of modelling how these losses may be distributed can begin to give us a sense of the potential additional risk that may reside in this segment of the market. In this exploratory study, we begin by distributing losses on a pro rata basis by various measures of company size (i.e., by premiums written, by equity or by risk retroceded). More generally, losses can be distributed randomly. 


\subsection{Geographical regions}

Though reinsurance is a global market, some companies participate to a greater extent in regional business than others. To explore the importance of varying degrees of regionalization/globalization among retrocessionaires, we differentiate reinsurers by region. The largest reinsurers are assumed to participate equally in all regions. Smaller reinsurers headquartered in North America and Bermuda are considered to be in the North American region. Smaller reinsurers headquartered in Europe are considered to be in the European region, while smaller reinsurers headquartered in Asia are considered to be in the Asian region.

When a catastrophe happens, we consider reinsurers lying in the region in which the catastrophe occurs to bear a bigger portion of the losses than those outside the region. This is fairly consistent with industry practice, although we do test the sensitivity of our results to these assumptions.

The percentage/portion of the losses divided by reinsurers in the region is called the "in region ratio."

\subsection{Scenarios}

Combining sections 5.2 and 5.3, there will be six scenarios for each pair of user-defined parameters $(\alpha$ and $\beta$ ) that we shall study. Some of the analysis results are graphed below.

\subsection{Parameters}

The model we present has many parameters. We describe them and our key assumptions concerning their values here.

a. Loss recovery rate (RL): Losses recovered by reinsurers. There are two loss recovery rates since there are two model layers. Loss recovery rate $1\left(\mathrm{RL}_{1}\right)$ describes the percentage of the losses recovered by reinsurers in the first layer. Loss recovery rate $2\left(R_{2}\right)$ refers to the percentage of the losses recovered by reinsurers in the second layer (from retrocession counterparties). As discussed in Section 5.1, we believe $\mathrm{RL}_{1}$ between 40 and 70 per cent is a reasonable value and use 50 per cent as a base case. According to a report estimating the losses for Hurricane Katrina, Munich Re (2005) believes the losses borne by reinsurers could be reduced in 
half after retrocessions. Given the fact that Hurricane Katrina was one of the biggest insured loss event in US history (Blake, Landsea and Gibney 2011) and the assumption that the bigger the event, the higher the proportion recovered from the retrocession layer, we believe that a 50 per cent recovery ratio for retrocession layer is also a reasonable value.

b. Number of events $(\mathrm{N})$ : The number of insurance events that happen in one year. We use US insured loss data, but broadly similar results are obtained using global losses. How we deal with the data and choose the value for the parameter is described in Section 4.2.

c. Level of loss (L): A scaling factor applied to determine the magnitude of a simulated loss. We calibrate historical catastrophe insured losses to follow a Pareto distribution, and apply scaling factor L. This is also described in Section 4.2.

d. Region (R): After determining the number of events, we also randomly decide the region of the event. We consider four regions: Global, North America, Europe and Asia.

e. The in-region ratio (RR): The percentage of the losses that are divided by the reinsurers in the region. Reinsurers not in the region divide up the remaining portion (1-RR). To model a situation in which counterparties trade more with their local peers, the default value used in our simulation is 80 per cent, but we investigate a large number of possible values.

f. Distribution type (D): The way the losses get distributed, i.e., pro rata by equity, pro rata by premium written, or pro rata by risk retroceded.

g. Fail criteria $(\alpha)$ : In our simulation, we compute Loss/Equity as fail criteria. If Loss/Equity $>\alpha$, the reinsurer is considered to fail. As discussed in Section 5.2, we pick $\alpha=0.9$ for our base case but perform sensitivity analysis around this.

h. Beta $(\beta)$ : The fraction of a reinsurer's assets that survive a bankruptcy. This is related to the "haircut," here (1- $\beta$ ). In the final portion of this paper, we investigate the impact of smaller (and hence more destructive) values for $\beta$ but display results from values of $\beta=0.9$ or larger. 


\section{SiMULATIONS AND RESULTS}

\subsection{Simulation process}

The simulation process is as follows:

Initialize variables: loss recovery ratio $\left(\mathrm{RL}_{1}, \mathrm{RL}_{2}\right)$, region ratio (RR), user-input fail criteria $(\alpha)$ and Beta $(\beta)$ if bankruptcy setting is considered.

a. Determine the way in which reinsured losses are distributed through the market (D).

b. Determine number of events (N), level of loss (L) as well as event's region $(\mathrm{R})$.

c. Draw a random number from a Pareto distribution to quantify the losses.

d. For each event, compute each reinsurer's losses in layer 1 and 2.

e. Sum up total losses for each reinsurer.

f. Apply the claims/equity $>\alpha$ fail criteria to determine if the given reinsurer should fail.

g. Work out the consequences of failures (as described in Section 5.2.2).

h. Iterate steps (c) to (g) 1,000 times.

\subsection{Results and Discussion}

\subsubsection{Results}

Four key results are obtained from our model simulations, as discussed below:

(1) First, the model gives plausible results both in the sense that intuitive mathematical relationships (larger losses $\rightarrow$ more reinsurer failures), and in the sense that historically observed levels of insured losses do not cause major damage to our model reinsurance market.

(2) The way losses are distributed among reinsurers and retrocessionaires makes a meaningful difference to failure rates. 
(3) Failure rates are sensitive to the leverage ratio ( $\alpha$ threshold) at which regulators/markets consider a reinsurer to be "bankrupt."

(4) Extreme scenarios generate outcomes that are significantly worse than the average results.

\subsubsection{Discussion}

(1) The loss levels at which significant "damage" begins to be observed in our model reinsurance industry are broadly consistent with what we might expect a priori.

Figure $2^{12}$ displays, in a non-bankruptcy setting, for a representative set of variables and for losses distributed pro rata by equity, the average fraction of reinsurers (number of reinsurers, asset and equity) in our sample that fail (vertical axis) as a function of the realized loss level (total insured losses, horizontal axis). These figures are obtained by simulating at several different disaster loss levels. Each simulation results in a particular realized loss, plotted on the horizontal axis, and leads to a certain fraction of companies, total assets and total equity failing. The average number of these fractions over 1,000 simulations is computed.

FIGURE 2 Average Percentage of Failure (Companies, Assets, Equity), Non-Bankruptcy, Losses Distributed by Equity

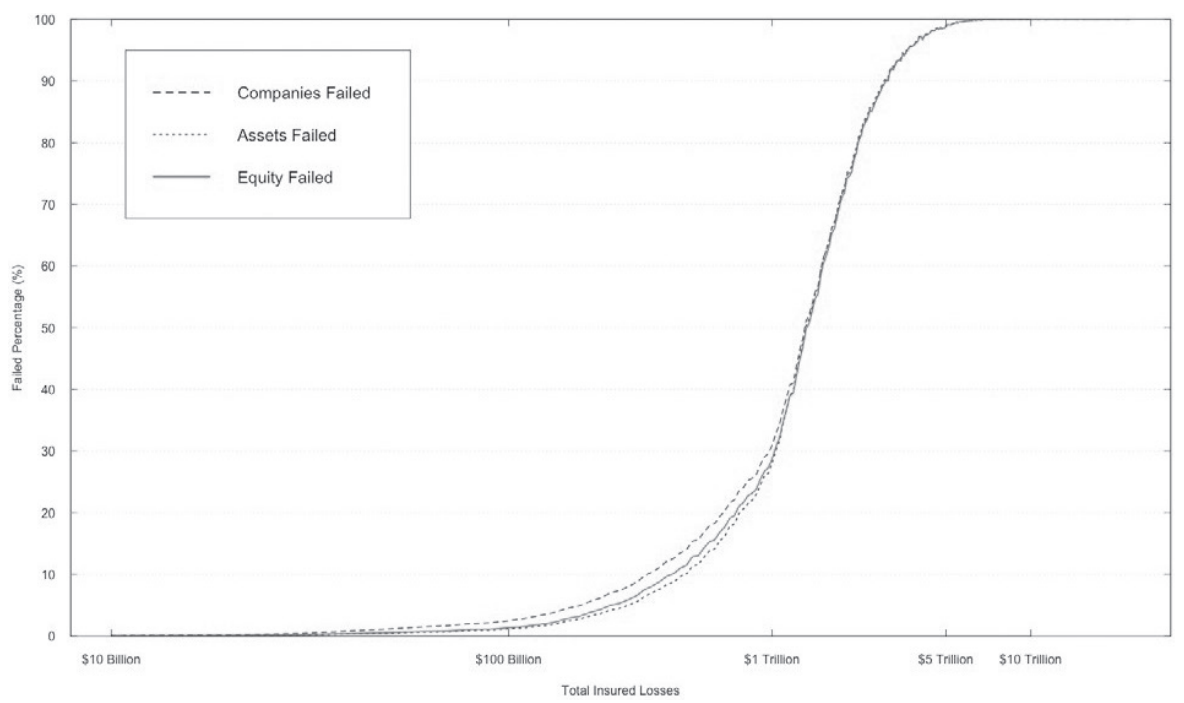


Figure 2 shows that, in our non-bankruptcy setting, few reinsurance failures are found for annual realized losses of $\$ 100$ billion or less. Since our 2010 data set has reinsurance market equity of about $\$ 1$ trillion, this makes sense. However, as losses increase toward the trilliondollar mark, more and more companies fail, reaching a situation in which about one-quarter of the companies representing about one-quarter of reinsurance assets and equity fail. The fact that not all the companies fail has to do with the way geographical distributions spare the companies. That said, once realized losses of more than about $\$ 4$ trillion are experienced, even companies with favourable geography begin to fail, overwhelmed by the sheer weight of losses. Note that the "phase transition" between few companies failing and most failing is particularly steep here. This makes sense, since we are distributing losses pro rata to the equity, the same financial variable used to decide which companies can bear the losses. So a quick transition from no failures to every company failing is to be expected.

Because losses are distributed pro rata by equity, it makes sense that the failure percentage reaches 100 per cent, since it implies that all companies actively participate in the market and trade with each other. As losses approach $\$ 5$ trillion, the whole reinsurance market is wiped out. The percentages of companies failed, assets failed and equity failed are fairly close to one another, as seen in Figure 2. This is because losses are distributed by equity and reinsurers' assets match their equity (i.e., a reinsurer with smaller equity tends to have smaller assets and vice versa).

(2) The way in which losses are distributed is very important.

Although losses are distributed, in each case here, through the system in a way proportional to measures of reinsurer strength (equity) or activity (premiums written, reinsurance ceded, etc.), each of which in turn might be expected to be at least somewhat related to one another, the exact details of which one is chosen matters a great deal. We choose some examples and present them below.

Figure $3^{13}$ displays, in a non-bankruptcy setting, for a representative set of variables and for losses distributed pro rata by premium written, the average fraction of reinsurers (number of reinsurers, assets and equity) in our sample that fail (failed percentage, vertical axis) as a function of the realized loss level (total insured losses, horizontal axis).

Figure 3 shows a more gradual increase in companies failing when the losses are distributed pro rata by total premium written in a non-bankruptcy setting. The failure percentage does not reach 100 per 
cent as in the previous graph. This is because, in 2010, some reinsurers in our sample reported total premium written of $\$ 0$, implying they may not participate in some lines of business. As disaster happens, our model here is assuming that these reinsurers will avoid the losses caused by the event and so remain unaffected by it.

\section{FIGURE 3 Average Percentage of Failure (Companies, Assets, Equity), Non-Bankruptcy, Losses Distributed by Premium Written}

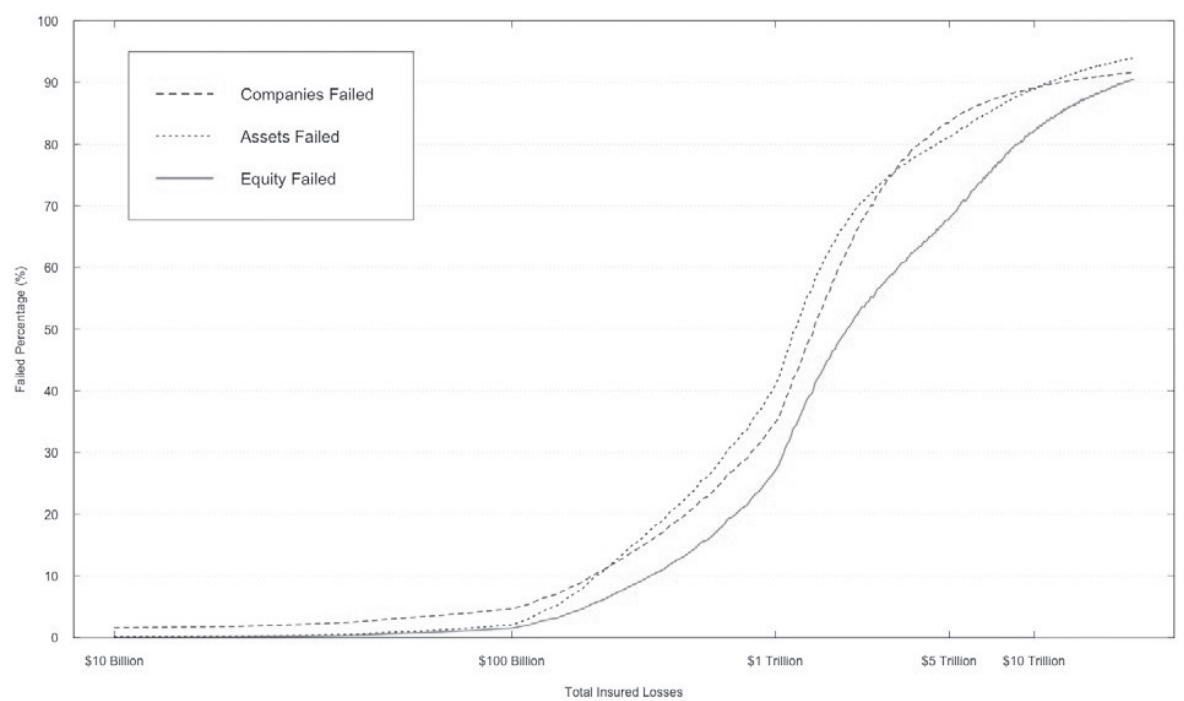

Figure $4^{14}$ displays, in a non-bankruptcy setting, for a representative set of variables and for losses distributed pro rata by total risk assumed, the average fraction of reinsurers (number of reinsurers, assets and equity) in our sample that fail (failed percentage, vertical axis) as a function of the realized loss level (total insured losses, horizontal axis).

In Figure 4, just as in Figure 3 and for similar reasons, the fraction of companies that fail does not reach 100 per cent. Here the percentage of companies/assets/equity failing also gradually increases with total insured losses but in a different pattern, especially with regard to the pattern by which the total fraction of equity fails. The graph of Figure 3 is smoother than the corresponding curve in Figure 4. The fraction of equity that fails dominates the percentage of assets failed after the trillion- dollar mark. This may imply that reinsurers with a relatively big equity/asset ratio tend to participate in the market more than others. 
FIGURE 4 Average Percentage of Failure (Companies, Assets, Equity), Non-Bankruptcy, Losses Distributed by Risk Assumed

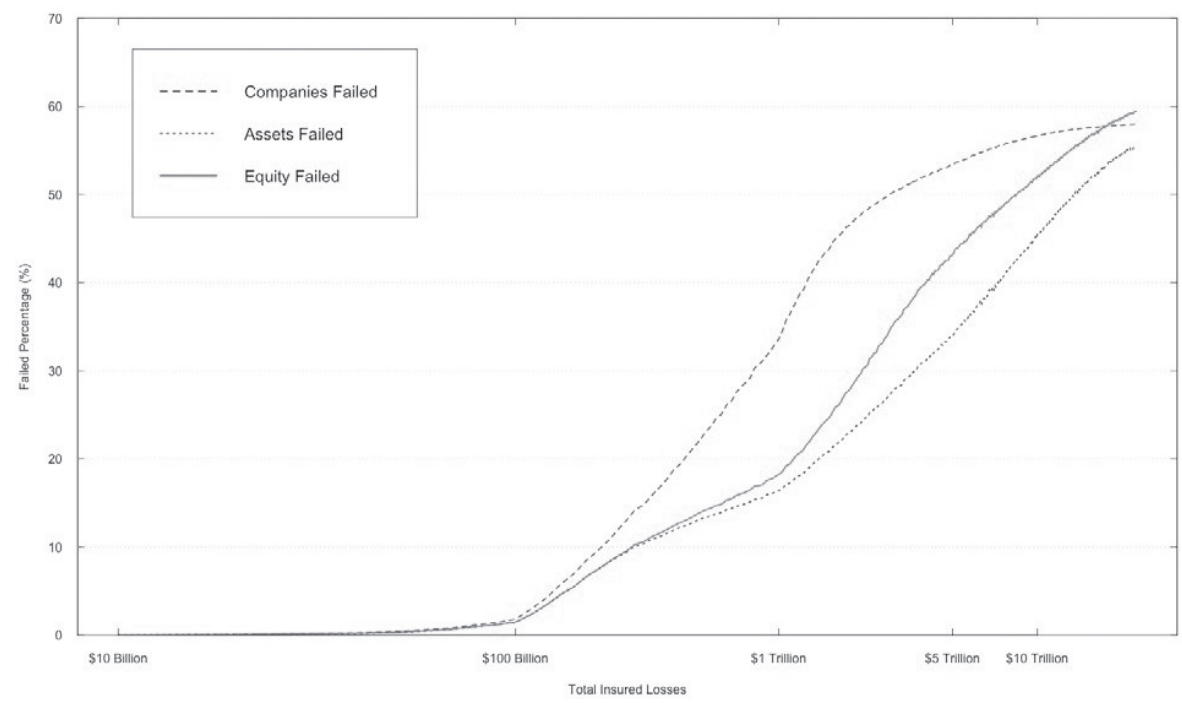

Figure $5^{15}$ displays, in a non-bankruptcy setting, for a representative set of variables and for losses distributed pro rata by total risk retroceded, the average fraction of reinsurers (number of reinsurers, assets and equity) in our sample that fail (failed percentage, vertical axis) as a function of the realized loss level (total insured losses, horizontal axis).

FIGURE 5 Average Percentage of Failure (Companies, Assets, Equity), Non-Bankruptcy, Losses Distributed by Risk Retroceded

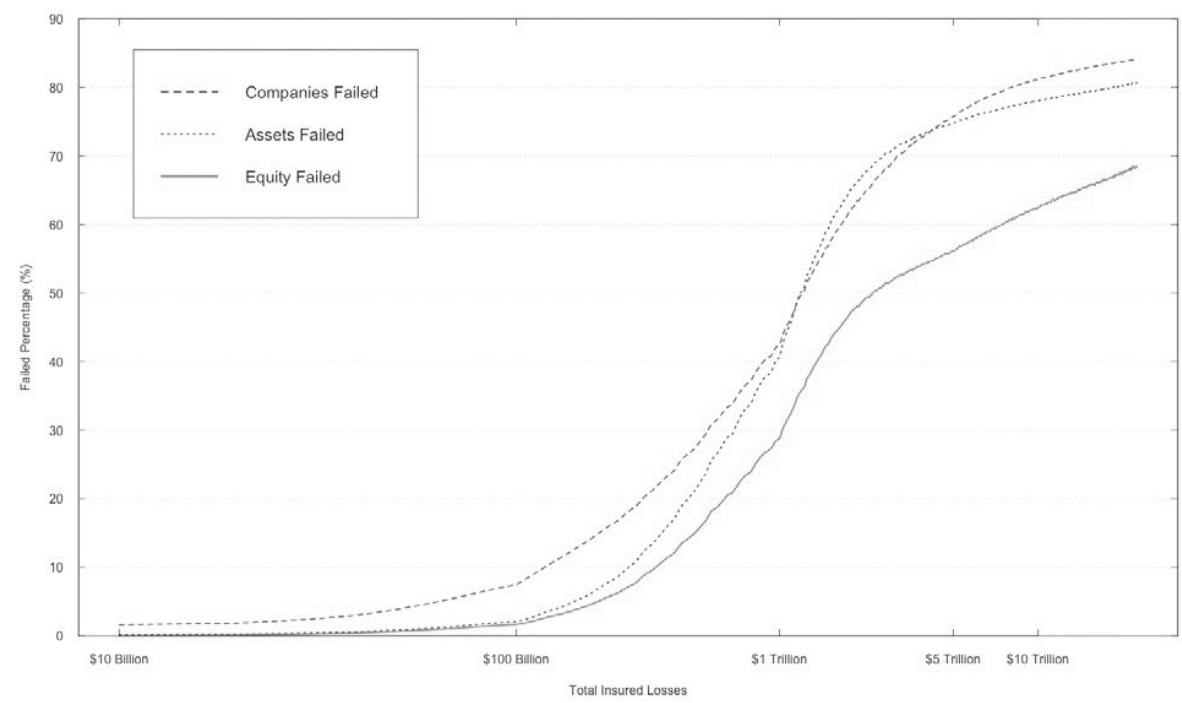


Figure 5 shows the failure percentage does not reach 100 per cent, just as for Figure 3, also for the reason that not all companies assume $\mathrm{P} \& \mathrm{C}$ risk. The percentage failing here gradually increases with total insured loss. Distinct from Figure 4, the percentage of assets is greater than the fraction of equity failed for most loss values. This may imply reinsurers with a relative big asset/equity ratio tend to participate in the market more than others.

Figure $6^{16}$ displays, in a non-bankruptcy setting, for a representative set of variables and for losses distributed pro rata by P\&C risk assumed, the average fraction of reinsurers (number of reinsurers, assets and equity) in our sample that fail (failed percentage, vertical axis) as a function of the realized loss level (total insured losses, horizontal axis).

Figure 6 shows the failure percentage due to losses distributed pro rata by risk assumed, particularly in the P\&C field. It presents a pattern different from that in Figure 4, although failure percentages continue to not reach 100 per cent because not all insurers retrocede $\mathrm{P} \& \mathrm{C}$ risk. But the percentage of equity failed also dominated over the percentage of assets failed after the trillion-dollar mark.

FIGURE 6 Average Percentage of Failure (Companies, Assets, Equity), Non-Bankruptcy, Losses Distributed by P\&C Risk Assumed

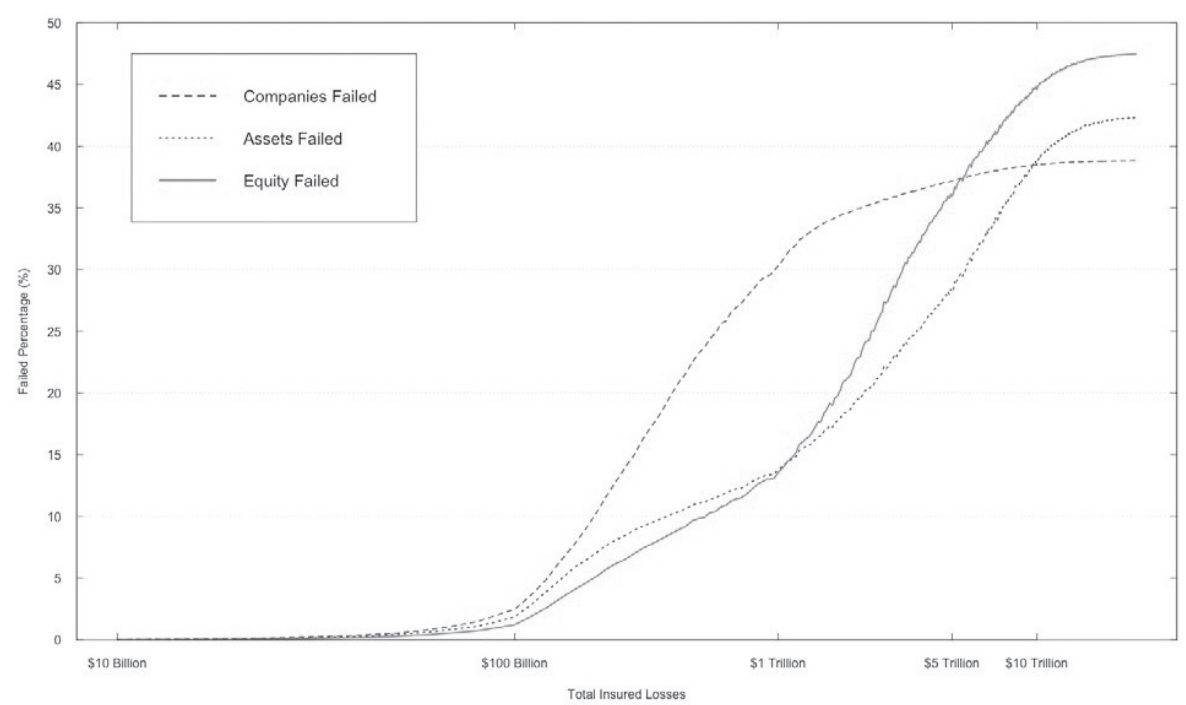


Figure $7^{17}$ displays, in a non-bankruptcy setting, for a representative set of variables and for losses distributed pro rata by P\&C risk retroceded, the average fraction of reinsurers (number of reinsurers, assets and equity) in our sample that fail (failed percentage, vertical axis) as a function of the realized loss level (total insured losses, horizontal axis).

Figure 7 shows the failure percentage does not reach 100 per cent as in Figure 3 and for the same reason. This figure shows failure percentage due to losses distributed pro rata by risk retroceded particularly in the P\&C field. In a way, it presents a similar pattern as losses distributed pro rata by total risk retroceded (Figure 5). As with figures 3 to 6 , we may infer that reinsurers tend to perform similarly in lines of business of risk retroceded but perform differently in lines of risk assumed.

FIGURE 7 Average Percentage of Failure (Companies, Assets, Equity), Non-Bankruptcy, Losses Distributed by P\&C Risk Retroceded

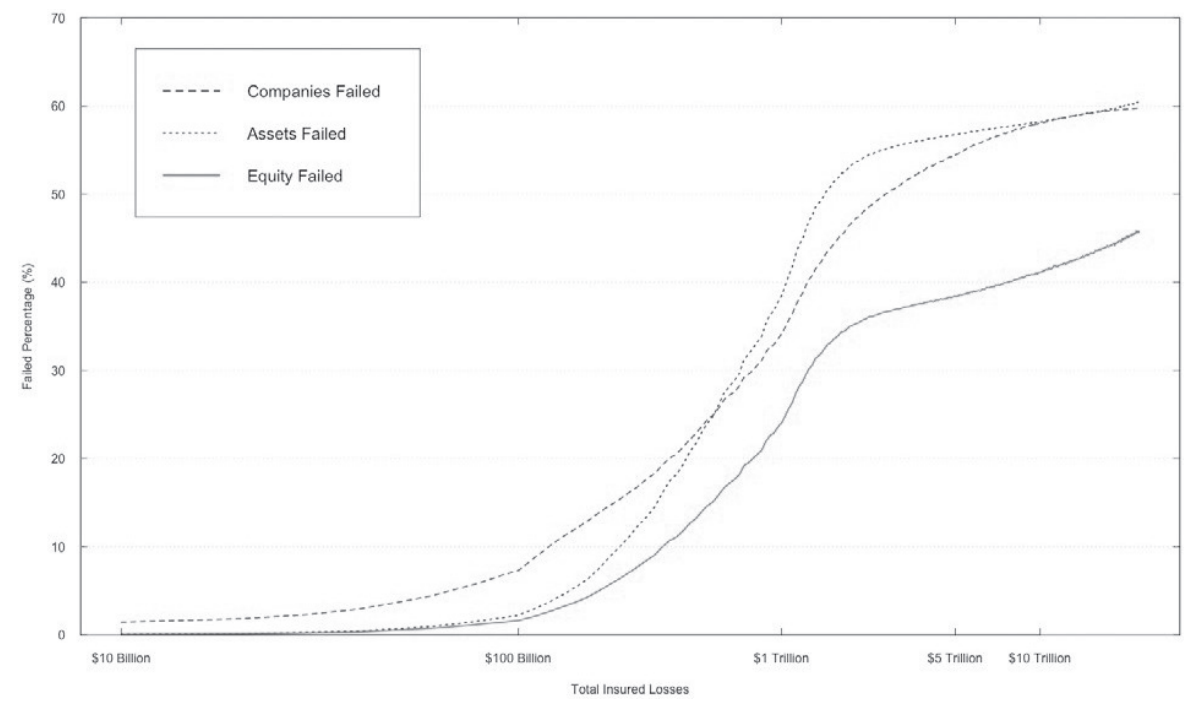

(3) The value of alpha matters a lot; the higher the alpha, the safer the market in a non-bankruptcy setting.

Figure $8^{18}$ displays, in a non-bankruptcy setting, for a representative set of variables and for losses distributed pro rata by premium written, the average fraction of reinsurers in our sample that fail (failed percentage, vertical axis) as a function of the alpha values (alpha, horizontal axis) at selected total insured loss levels. 
Figure 8 shows the number of reinsurers that fail, on average, for a given Pareto distribution scale level, as a function of the way in which losses are distributed, of the levels of total insured losses, and of the $\alpha$ parameter chosen in the non-bankruptcy setting. It is not surprising that a higher $\alpha$ leads to fewer losses, since a higher $\alpha$ represents a more "forgiving" failure threshold.

Of course, in reality, there is a trade-off: a lower value of $\alpha$ causes companies to be removed from the market before their bankruptcy can ignite a cascade; in the no-bankruptcy case examined in Figure 8, even failed companies may still satisfy all their claims, for the appearance of an increased safety with increased $\alpha$.

Figure 8 continues to display a setting in which increased insured losses lead to more failures; a curve with higher losses has, for every value of $\alpha$, more failures than a curve corresponding to lower losses. What is interesting here is to see how these losses vary with the failure threshold parameter $\alpha$. Figure 8 shows that, for lower levels of insured losses ( $\$ 100$ billion), few failures are ignited almost regardless of $\alpha$. For very large losses of $\$ 5$ and $\$ 10$ trillion, nearly all companies fail, again almost independent of $\alpha$. It is only for intermediate level of losses ( $\$ 500$ billion and $\$ 1$ trillion Pareto scale factor) that significant sensitivity to $\alpha$ is observed.

\section{FIGURE 8 Average Percentage of Failed Companies vs. Alpha at Selected Insured Losses, Non-Bankruptcy, Losses Distributed by Premium Written}

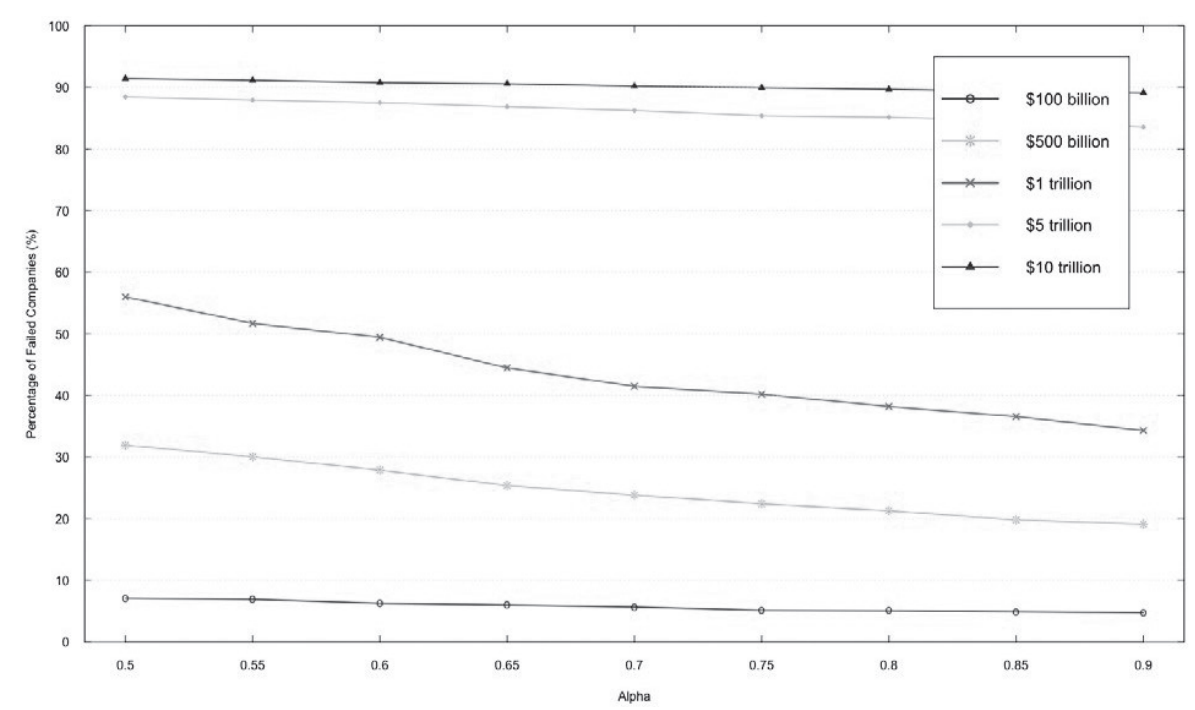


(4) The incorporation of the bankruptcy constraint, with the consequent inability of some firms to pay all claims, may result in a cascade in company failures and affect the stability of the network.

Figure $9^{19}$ displays, for a representative set of variables and for losses distributed pro rata by premium written, the average fraction of reinsurers failed (failed percentage, vertical axis) as a function of the realized loss level (total insured losses, horizontal axis) at different values of $\beta(0.9,0.95$ and 1$)$ and in comparison with non-bankruptcy setting where beta is not considered.

Figure 9 compares the average failed percentage of companies at different values of $\beta$ with that in non-bankruptcy setting ( $\beta$ not considered) where all other parameters are the same. Here "No $\beta$ " means no bankruptcy; as discussed above, this is not the same as a beta of 1.0. As $\beta$ varies from 0.9 to 1.0 , we see that the percentage of companies failing decreases at any given loss level. This makes sense: the lower the $\beta$, the more economic insolvency cost is added to the industry, over and above the reinsurance loss. For insured losses less than about $\$ 100$ billion, few losses are observed regardless of $\beta$; for losses above about $\$ 1$ trillion, again $\beta$ is irrelevant (as long as there is some bankruptcy process modelled), perhaps because, in this case, the really big losses coming from the fat tails of the Pareto loss distribution employed here are destroying companies whether all their assets or just a small fraction are available to settle claims. The bankruptcy and non- bankruptcy scenarios do start to show a difference after around $\$ 250$ billion of total insured losses. This will be further discussed in the discussion of Figure 10. A total insured loss level of $\$ 250$ billion is relatively big compared with the historical disaster loss experience. From this perspective, we may draw the preliminary conclusion that the current global reinsurance industry is potentially fairly robust from a solvency perspective under a range of conditions.

Figure $10^{20}$ displays, for a representative set of variables and for losses distributed pro rata by premium written, the average percentage of the companies in the reinsurance market (failed percentage, vertical axis) due to cascade as a function of the realized loss level (total insured losses, horizontal axis) at alpha $=0.9$ and beta $=1$ in a bankruptcy scenario.

Figure 10 shows that, for total insured losses of less than about $\$ 100$ billion, few cascade events are detected. Bankruptcy failure cascades have their maximum impact at insured losses of about $\$ 1$ trillion, 
FIGURE 9 Average Percentage of Failure (Companies) at Different Values of Beta in Bankruptcy and Non- Bankruptcy for Alpha Fixed at 0.9, Losses Distributed by Premium Written

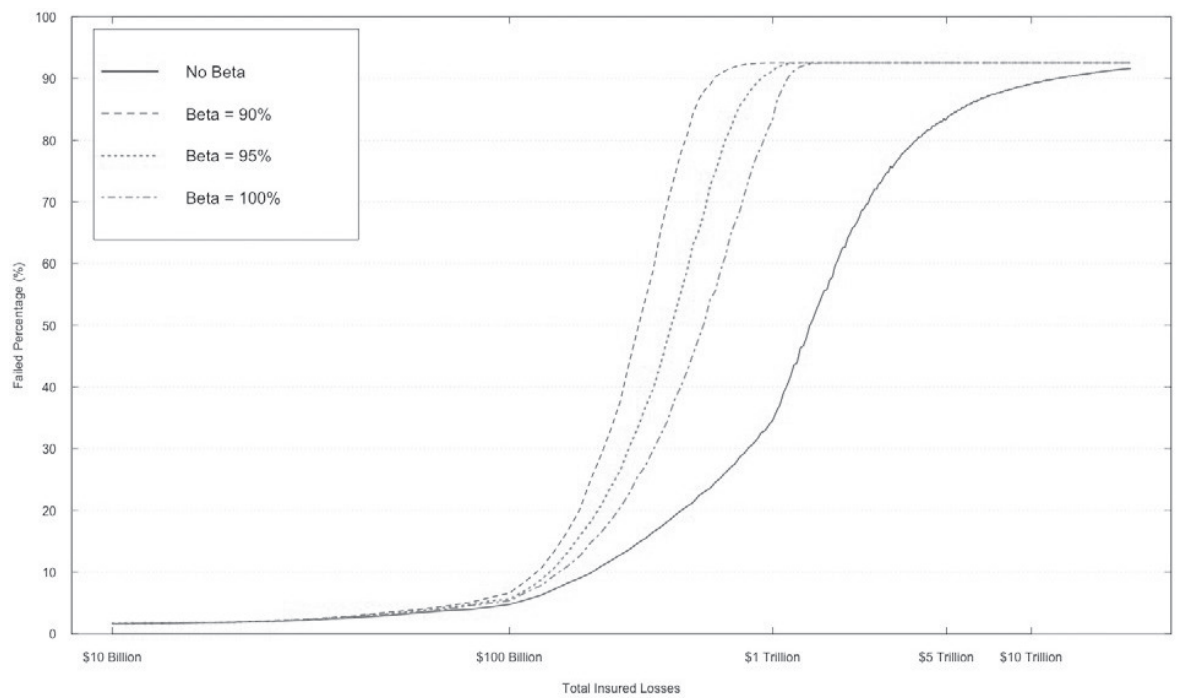

FIGURE 10 Average Number of Failed Companies Due to Cascade in Bankruptcy Scenario

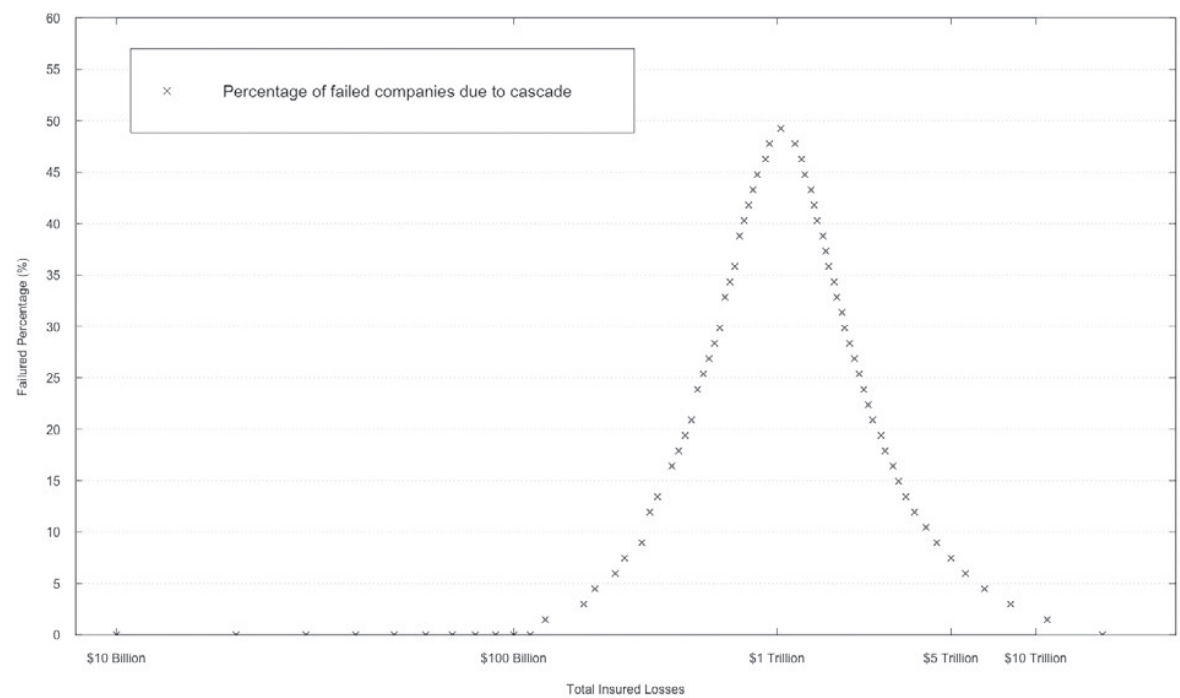


after which they again become less important. This is because, for very large total insured losses, companies fail because of the direct claims against them and do not survive long enough to be taken down by the inability of their counterparties to repay them.

(5) Each disaster is simulated to come from a particular geographic region and is preferentially distributed among reinsurers in that region, as described below.

Figure $11^{21}$ displays, in a non-bankruptcy setting, for a representative set of variables and for losses distributed pro rata by premium written, the average number of reinsurers failed (failed percentage, vertical axis) as a function of the realized loss level (total insured losses, horizontal axis) at various region ratios and no region effect considered.

The curves in Figure 11 differ in the way in which the region of each reinsurer is considered. For a particular region ratio considered, the reinsurers domiciled in the region in which the disaster happens divide up the specified "region ratio" fraction (region ratio $=0,0.5,0.9$ and 1) of the losses; the remaining insurers domiciled outside the region take the remaining part. In the "no region effect is considered" case, all reinsurers are considered to be in the same region. In the bankruptcy scenario, the effect of not considering regional effects is quite close to the case where the region ratio equals 0 , which makes sense since, in both cases, losses are effectively blended across regions. As the region ratio grows larger, the fraction of companies that fail becomes smaller and smaller. The market is compartmentalizing and, while reinsurers in a disaster-struck region may be more likely to fail, companies in other regions may be more likely to survive, making the entire market is less likely to fail. But if the region effect is not considered, it is close to the case where half the losses are undertaken by reinsurers in the region where the disaster happens. This potentially means that globalization of the reinsurance market may not help with the failures.

The final set of calculations presented here investigates the stability of the market if some large reinsurers are removed. The basic form of the failure outcomes against total insured loss does not change their shapes. However, it is not extremely surprising that more failures are observed with the removal of reinsurance market capacity. We removed the large globally important insurers Generali and AIG as well as Berkshire Hathaway, whose many large non-insurance business lines contribute to many imponderables. Figure 12 depicts, apart from the 
FIGURE 11 Average Number of Failed Companies Due to Various Region Effects

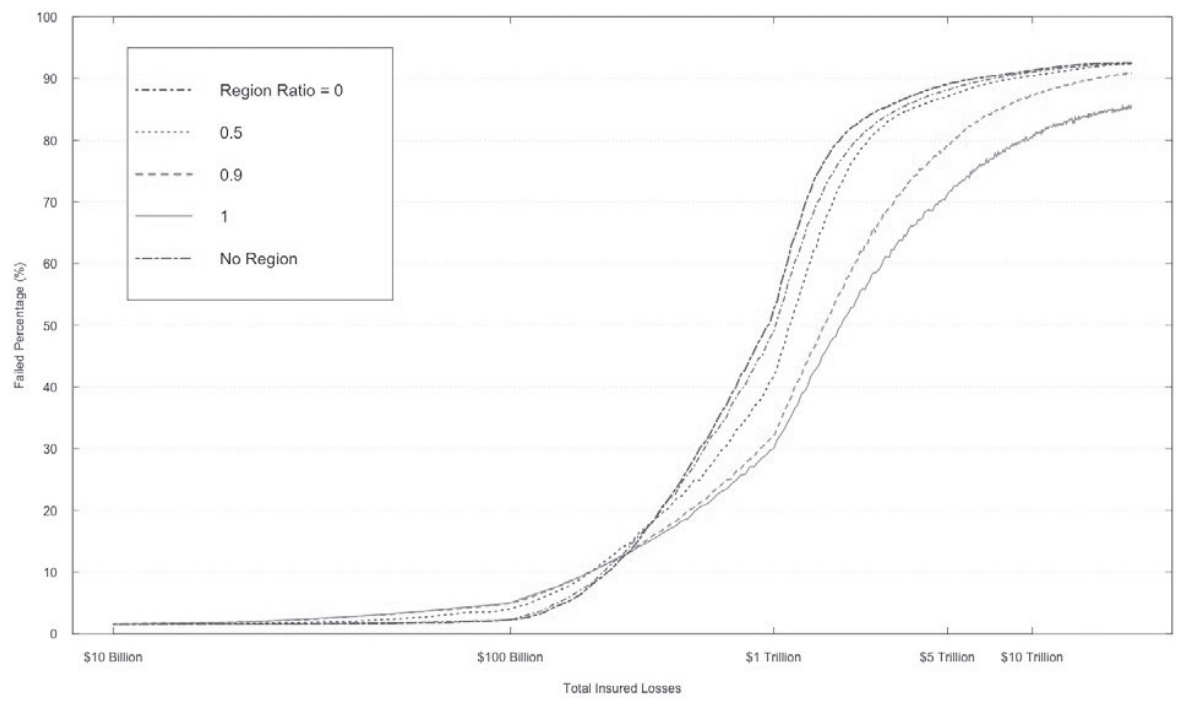

FIGURE 12 Average Percentage of Failure (Companies, Assets, Equity), Non-Bankruptcy, Losses Distributed by Equity. Same parameters as Figure 2, only difference being that AIG, Generali and Berkshire Hathaway are removed

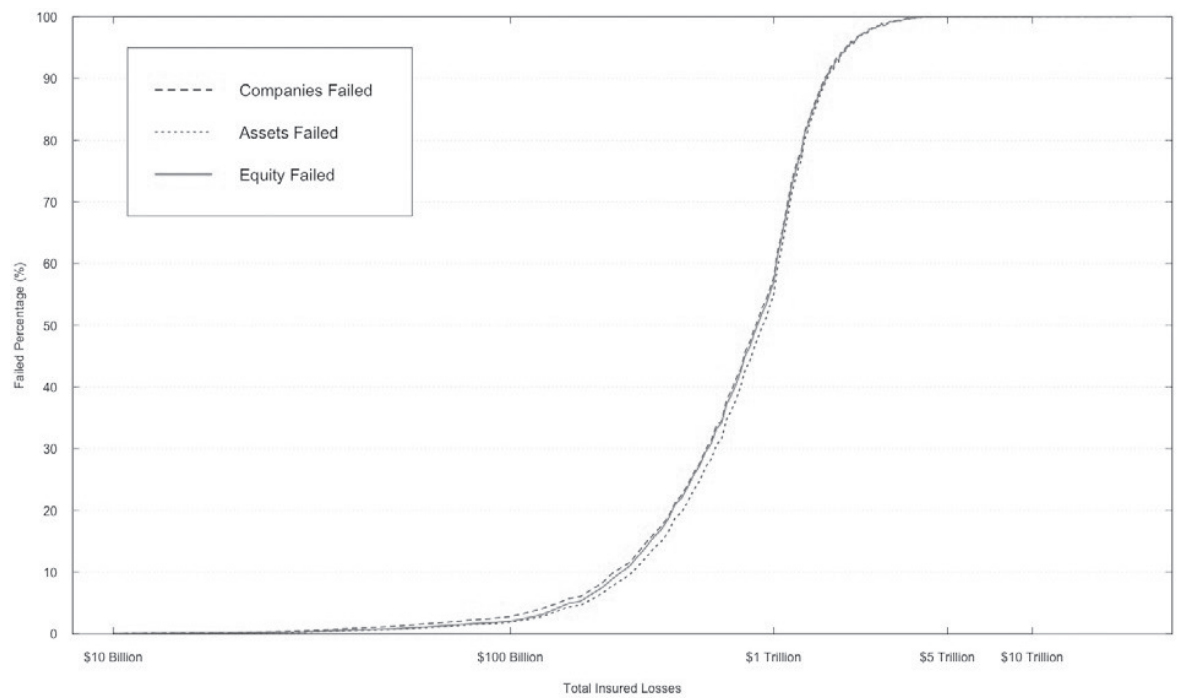


removal of these larger insurers, a calculation similar to that reported in Figure 2. One can see that, at $\$ 1$ trillion of total insured loss, the failed fraction rises to about one half from the one quarter reported in Figure 2; as well, some damage to the reinsurance market is now experienced at a total insured loss of about half a trillion. Even with the removal of these large participants, the reinsurance market is still quite robust.

\section{Overall ConcLusions}

Although based on relatively crude assumptions, the above calculations and their discussion allow for some overall conclusions.

(1) The stability of the reinsurance industry appears to be fairly robust. It would take a catastrophic event larger than any experienced in recent history to result in material failures within the industry. There are relatively few such potential events, although one such might be a Miami hurricane.

(2) The organization of the retrocession industry is not observable to us but, using some assumptions, it can be simulated. The detail of this organization does matter, especially for losses large enough to bring down reinsurers, but which are not so large as to completely devastate the entire industry. Modelling details about the loss level required to force exit from the industry $(\alpha)$ and about the haircut in the event of default variable $(\beta)$, both seem to matter, at least for loss levels big enough to do some damage but small enough to not obviously wreck the entire industry; the existence of groups inside the industry that preferentially exchange risks within themselves is also quite important. Under certain assumptions, the industry is more vulnerable in that the order of magnitude of the losses needed to initiate a cascade is different.

(3) Bankruptcy assumptions do not affect the level of the catastrophe required to initiate a cascade; however, the $\beta$ assumption does highlight the fact that the cascade can be sensitive to any correlations that may exist in the tail (i.e., the macroeconomic policy choices following a sufficiently large event will matter). 


\section{Future DiReCtions}

In the above work, we have presented a framework for going from the limited amount of data available about the reinsurance market to a modelling framework that allows these data to be used to generate interesting "what if" scenarios. The results we have displayed are broadly consistent with our intuition about these models.

Our work requires some assumptions about the degree to which the reinsurance community is able to handle dealing with risky counterparties. In our work, we parameterize this by $\alpha$ and the value of this parameter can matter a great deal. We also require information about the geographical heterogeneity of the market, which appears to provide some "bulkheads" between various regions, at least with the parameters used here. We also have a parameter that details the degree to which liquidating positions to pay debts incurs costs: our $\beta$. The value of this is normally quite high, leading to safe results; however, in a scenario with a major insurance disaster coinciding with a global financial crisis, the impact of liquidity discounts can be devastating to our model.

The problem of modelling the world reinsurance market has two main sources of uncertainty. First, the number and magnitude of property and casualty disasters to be experienced in the upcoming year are uncertain. Second, the detailed structure of the reinsurance market is also uncertain, in terms of the counterparties to any reinsurance contract and also in terms of the details of the contract. Indeed, as we have discussed above, the counterparties to a retrocession agreement may not even be known by the participants until the agreement is signed, much less by analysts!

It is relatively easy to model the disaster risk using standard actuarial or mathematical finance tools. We know how many disasters of a given size have struck over many past years, as well as their size. This allows probability distributions to be made for both number and size, and hypothetical future years can be simulated from these distributions. This is what we have done to this point in constructing our corporate bankruptcy simulations.

Our approach thus far has been to make logical distributions of risk: pro rata by various financial statement metrics like equity, premium written, or reinsurance assumed, possibly weighted in addition by geographic factors. 
However, these ways of distributing deal sizes are, by their very nature, likely to distribute risk to those most able to assume it. As such, we find that very large losses are needed to force wholesale insurance market failures. (If netting is done before failure, these are very large losses indeed, while applying bankruptcy on gross losses makes for a slightly more fragile system.)

What we want to focus on is market structures that can lead to much more serious failure cascades. We can do this by somehow putting a probability distribution on the constraint-satisfying matrices of links (difficult to do, given the information we possess). But we can also take a different leaf from the risk manager's book and look for dangerous scenarios.

For example, from a traditional risk-management setting, one way to determine the risk in an options book is to simulate the price of all the underlying assets and compute tail-based risk measures such as VaR or CVaR. Another way is to think about what kind of things might reasonably go wrong. Social scientists do this using a very disciplined and formalized approach in broader, non-financial risk settings where it goes under the heading of "foresight analysis."

We can do the same thing by devising connection matrices (particularly at the second or "retrocession" stage) designed to wreak maximum havoc and devastation on the world reinsurance market. Finding such connection matrices does not imply that this worst-case scenario will happen, merely that it conceivably might.

\section{BIBLIOGRAPHY}

[1] Acharya, V. V., J. Biggs, M. Richardson, and S. Ryan. 2009. "On the Financial Regulation of Insurance Companies." NYU Stern School of Business working paper.

[2] Aon Benfield. 2015a. Reinsurance Market Outlook. Chicago: Aon. Retrieved March 08, 2015, from http://thoughtleadership.aonbenfield.com/ Documents/20150102_ab_analytics_reinsurance_marke t_outlook_ january2015.pdf.

[3] Aon Benfield. 2015b. Insurance-Linked Securities: Alternative Markets Adapt to Competitive Landscape. September 2015. http://thoughtleadership.aonbenfield.com/sitepages/display.aspx?tl=530. 
[4] Australian National Audit Office (ANAO). 2004. HIH Claims Support Scheme-Governance Arrangements. Audit Report No. 51 2003-04 Performance Audit.

[5] Bain, A. 1999. "Insurance Spirals and the London Market." Geneva Papers on Risk and Insurance Risk and Insurance, Vol 24:2.

[6] Berger, L. A., D. Cummins and S. Tennyson. 1992. "Reinsurance and the Liability Insurance Crisis." Journal of Risk and Uncertainty 5(3): 253-272.

[7] Bibas, R., H. Stéphane and S. Lemoyne de Forges. 2011. "A Dynamic Model of Extreme Risk Coverage: Resilience and Efficiency in the Global Reinsurance Market." The World Bank Policy Research Working Paper WPS5807, Sustainable Development Network, Office of the Chief Economist.

[8] Billio, M., M. Getmansky, A. W. Lo and L. Pelizzon. 2012. "Econometric Measures of Systemic Risk in the Finance and Insurance Sectors." Journal of Financial Economics 104:3.

[9] Blake, E. S., C. W. Landsea and E. J. Gibney. 2011. "The Deadliest, Costliest, and Most Intense United States Tropical Cyclones from 1851 to 2010 (and other frequently requested hurricane facts).” Miami: NOAA.

[10] Carolan, M., Z. Charachafchi, W. O'Neill and N. Sharma. 2009. "Coping with the CDS Crisis: Lessons Learned from the LMX Spiral." Journal of Reinsurance 16:2

[11] Cummins, J. and M. Weiss. 2011. "Systemic Risk and the US Insurance Sector." Available at SSRN: http://ssrn.com/abstract=1725512 or http:// dx.doi.org/10.2139/ssrn.1725512.

[12] Dahlen, S.V. and G. V. Peter. 2012. "Natural Catastrophes and Global Reinsurance-Exploring the Linkages." BIS Quarterly Review (December).

[13] Dahlen, S. V., G. V. Peter and S. Saxena. 2012. "Unmitigated Disasters? New Evidence on the Macroeconomic Cost of Natural Catastrophes." BIS Working Paper No. 394, Monetary and Economic Development.

[14] Fields, J. A., L. Klein and E. Myskowski. 1998. "US Property and Liability Insurance Industry." Journal of Risk and Uncertainty 16:2.

[15] Galbraith, John K. and James K. Galbraith. 2009. The Great Crash 1929. New York: Houghton Mifflin Harcourt.

[16] GAO. 1988. Liability Insurance: Effects of the Recent 'Crisis' on Businesses and Other Organizations. Washington, DC: United States General Accounting Office. 
[17] Geneva Association. 2010. Systemic Risk in Insurance: An Analysis of Insurance and Financial Stability. Special Report of the Geneva Association Systemic Risk Working Group. Geneva: The Geneva Association.

[18] Garcia, A. and R. Gencay. 2007. "Applications of Extreme Value Theory to Collateral Valuation." Journal of Financial Transformation 20: 88-93.

[19] Grace, M. F. 2010. "The Insurance Industry and Systemic Risk: Evidence and Discussion." Networks Financial Institute Policy Brief No. 2010-PB-02.

[20] Group of Thirty. 2006. "Reinsurance and International Financial Markets." Occasional Paper. Working Group on Reinsurance.

[21] Harrington, S. E. 2009. "The Financial Crisis, Systemic Risk, and the Future of Insurance Regulation." Journal of Risk and Insurance 76:4.

[22] IAIS. 2010. Global Reinsurance Market Report: End Year Edition. Basel, Switzerland: International Association of Insurance Supervisors.

[23] IAIS. 2012. Reinsurance and Financial Stability. Basel, Switzerland: International Association of Insurance Supervisors.

[24] Kampman, M., I. Lelyveld and F. Liedorp. 2011. "An Empirical Assessment of Reinsurance Risk." Journal of Financial Stability 7.

[25] Kehl, David. 2001. HIH Insurance Group Collapse. E-brief: Parliament of Australia. http://www.aph.gov.au/About_Parliament/Parliamentary_ Departments/Parliamentary_Library/Publications_Archive/archive/ hihinsurance.

[26] Munich Re. 2005. Munich Re Can Still Achieve Its Result Target for 2005. http://www.munichre.com/en/ir/publications/ad-hoc/2005/ 2005-12-29-ad-hoc/index.html?QUERYSTRING=retrocession.

[27] PACICC, 2008. "Why Insurers Fail: The Dynamics of Property and Casualty Insurance Insolvency in Canada." Toronto, ON: Property and Casualty Insurance Compensation Corporation. Available at: http:// www.pacicc.ca/publications/pages/publications/WIF\%20Dynamics\%20 of $\% 20 \mathrm{P} \& \mathrm{C} \% 20$ Insuran ce.pdf.

[28] Park, S. C. and X. Xie. 2014. Reinsurance and Systemic Risk: The Impact of Reinsurer Downgrading on Property-Casualty Insurers. Journal of Risk and Insurance 81 (3): 587-622.

[29] Romano, Roberta. 1989. "What Went Wrong with Directors' and Officers' Liability Insurance?” Yale Law School Faculty Scholarship Series. 
[30] Sheldon, G. and M. Maurer. 1998. "Interbank Lending and Systemic Risk: An Empirical Analysis for Switzerland." Swiss Journal of Economics and Statistics 134: 685-704.

[31] Shiu, Yung-Ming. 2011. "Reinsurance and Capital Structure: Evidence From the United Kingdom Non-Life Insurance Industry." Journal of Risk and Insurance 78:2.

[32] Stanard, James N. and Michael G. Wacek. 1991." The Spiral in the Catastrophe Retrocession Market." Casualty Actuarial Society Discussion Paper Program, 539-559.

[33] Statista. 2014. "The Most Expensive Natural Disasters in 2011, by Insured and Total Losses." Retrieved from http://www.statista.com/ statistics/276706/most-expensive-natural-disasters-in-2011-by-insured-andoverall-losses/.

[34] Upper, C. and A. Worms. 2004. "Estimating Bilateral Exposures in the German Interbank Market: Is there a Danger of Contagion." European Economic Review 48 (4): 827-849.

[35] Winter, Ralph A. 1991. "The Liability Insurance Market." Journal of Economic Perspectives 5:3.

\section{NOTES}

1 The authors would like to thank the University of Guelph (Humber) for supporting this research and thank Muhammad Hussein for excellent research assistance. We also thank Western University student Guqian Zhao for excellent computing assistance.

2 Western University, London, Ontario

3 Office of the Superintendent of Financial Institutions, Ottawa, Ontario

4 Corresponding author, Canadian Economic Analysis Department, Bank of Canada, Ottawa, Ontario, Canada, K1A 0G9

5 Corresponding author, Canadian Economic Analysis Department, Bank of Canada, Ottawa, Ontario, Canada, K1A 0G9, jvoll@bankofcanada.ca

6 Under a typical reinsurance contract, a single reinsurer or syndicate of reinsurers assumes responsibility for a primary insurer's potential losses above a certain threshold in exchange for a reinsurance premium. Settlements from reinsurers are often critical to insurers' ability to meet claims obligations following major catastrophes. (Insurance Information Institute, Reinsurance Issues Update, http://www.iii.org/issue-update/ reinsurance).

7 A key reason for the lack of study of the retrocession market is the lack of data. In most jurisdictions, reinsurers are not required to disclose their retrocession counterparties or the nature of their counterparty arrangements.

8 This conclusion is based on A.M. Best insolvency reports. It should be noted that these reports identify the proximate causes of insolvency. Research by Canada's PACICC reviewing both the proximate and the contributing causes of Canadian insolvencies identified that reinsurance was a factor (primarily as a contributing rather than proximate factor) in 26 per cent of primary insurance insolvencies (PACICC 2008).

9 Warren Buffett, Chairman's Letter to shareholders. 2002. http://www.berkshirehathaway.com/ letters/2002pdf.pdf, page 15. 
10 It is true that claims are not always fully paid in the year in which the disaster occurs; however, insurers should report their best estimate on the financial statements. However, an insurer or reinsurer may not have a good estimate or may use methodologies that might underestimate the size of losses in a given year, adjusting this on its financial statements over time. This is sometimes done with the tacit approval of regulators who may see this as a way to mitigate the risk of insolvency. For example, this was widely reported in insurance trade publications to be the case for Kemper Insurance that reportedly received special dispensation for deviations from normally accepted accounting procedures.

11 Based on data from PACICC, liquidations for P\&C insurance companies in Canada have historically had asset recoveries of approximately between 45 and 95 per cent.

12 Figure 2 is based on the following: Ten loss events annually, each drawn from a Pareto distribution with scale parameter 1.5529. Non-bankruptcy setting. Loss distributed by equity. Alpha is calculated as net loss/ equity and fixed at 0.9 . Parameters: entire loss level from $10^{9}$ to $10^{12} ; \mathrm{L}_{1}=0.5, \mathrm{RL}_{2}=0.5, \mathrm{RR}=0.8$. Simulation runs 5,000 times.

13 Figure 3 is based on the following: Ten loss events annually, each drawn from a Pareto distribution with scale parameter 1.5229. Non-bankruptcy setting. Losses distributed by premium written. Alpha is calculated as net loss/equity and fixed at 0.9. Parameters: entire loss level from $10^{9}$ to $10^{12}$. $R L_{1}=0.5, R L_{2}=0.5$, $\mathrm{RR}=0.8$. Simulation runs 5,000 times.

14 Figure 4 is based on the following: Ten loss events annually, each drawn from a Pareto distribution with scale parameter 1.5229. Non-bankruptcy setting. Losses distributed by total risk assumed. Alpha is calculated as net loss/equity and fixed at 0.9. Parameters: entire loss level from $10^{9}$ to $10^{12}$. $R L_{1}=0.5, R L_{2}=0.5$, $\mathrm{RR}=0.8$. Simulation runs 5,000 times.

15 Figure 5 is based on the following: Ten loss events annually, each drawn from a Pareto distribution with scale parameter 1.5229. Non-bankruptcy setting. Distribution type: by risk retroceded. Alpha is calculated as net loss/equity and fixed at 0.9. Parameters: entire loss level from $10^{9}$ to $10^{12}$. $R L_{1}=0.5, R_{2}=0.5$, $\mathrm{RR}=0.8$.Simulation runs 5,000 times.

16 Figure 6 is based on the following: Ten loss events annually, each drawn from a Pareto distribution with scale parameter 1.5229. Non-bankruptcy setting. Distribution type: by P\&C risk assumed. Alpha is calculated as net loss/equity and fixed at 0.9. Parameters: entire loss level from $10^{9}$ to $10^{12}$. $R L_{1}=0.5, R L_{2}=0.5$, $\mathrm{RR}=0.8$. Simulation runs 5,000 times.

17 Figure 7 is based on the following: Ten loss events annually, each drawn from a Pareto distribution with scale parameter 1.5229. Non-bankruptcy setting. Distribution type: by P\&C risk retroceded. Alpha is calculated as net loss/equity and fixed at 0.9 . Parameters: entire loss level from $10^{9}$ to $10^{12}$. $\mathrm{RL}_{1}=0.5, \mathrm{RL}_{2}=0.5$, $\mathrm{RR}=0.8$. Simulation runs 5,000 times.

18 Figure 8 is based on the following: Ten loss events annually, each drawn from a Pareto distribution with scale parameter 1.5229. Non-bankruptcy setting. Distribution type: by premium written. Alpha is chosen from 0.5 to 0.9. Parameters: entire loss level from $10^{9}$ to $10^{12}$. $R L_{1}=0.5, R L_{2}=0.5, R R=0.8$. Simulation runs 5,000 times.

19 Figure 9 is based on the following: Ten loss events annually, each drawn from a Pareto distribution with scale parameter 1.5229. Bankruptcy setting. Distribution type: by premium written. Alpha is calculated as net loss/equity and fixed at 0.9. Beta $=0.9$. Parameters: entire loss level from $10^{9}$ to $10^{12}$. $R L_{1}=0.5, R L_{2}=0.5$, $\mathrm{RR}=0.8$. Simulation runs 5,000 times.

20 Figure 10 is based on the following: Ten loss events annually, each drawn from a Pareto distribution with scale parameter 1.5229. Bankruptcy setting. Distribution type: by premium written. Alpha is calculated as net loss/equity and fixed at 0.9 . Beta $=1.0$. Parameters: entire loss level from $10^{9}$ to $10^{12}$. $\mathrm{RL}_{1}=0.5$, $\mathrm{RL}_{2}=0.5, \mathrm{RR}=0.8$. Simulation runs 5,000 times.

21 Figure 11 is based on the following: Ten loss events annually, each drawn from a Pareto distribution with scale parameter 1.5229. Non-bankruptcy setting. Distribution type: by premium written. Alpha is calculated as net loss/equity and fixed at 0.9. Parameters: entire loss level from $10^{9}$ to $10^{12}$. $R L_{1}=0.5, R L_{2}=0.5$. Simulation runs 5,000 times. 


\section{APPENDIX 1: \\ EXAMPLES OF INSURANCE INDUSTRY CRISES WITH MACROECONOMIC CONSEQUENCES}

\section{HIH Insurance}

In August 2001, the HIH Insurance group failed and was placed into liquidation. While HIH Insurance operated internationally in the United Kingdom and the United States, the majority of its business was in Australia. The failure was the largest corporate failure in Australia's history and for policy holders and losses are estimated at 0.5 per cent of Australia's GDP at the time of liquidation. The failure of HIH Insurance was not a globally significant event and has also been identified as not being a domestic systemic event (Geneva Association 2010). However, the failure exhibited two characteristics of a crisis event: an impact on the real economy, and the deployment of taxpayer funds to mitigate the impact of the event.

To protect policy holders, seven of eight state and territory governments announced rescue packages and introduced new taxes and levies to fund policy-holder bailouts in homeowner and automobile insurance and in workers' compensation. Finally, the federal government announced the formation of the HIH Claims Support (HCS) to process the federal support package (Kehl 2001). The Appropriation (HIH Assistance) Act 2001 provided for $\$ 640$ million to provide compensation for policy holders. The auditor estimated that the final cost would be $\$ 812$ million (ANAO 2004).

Reinsurance was not a proximate cause of the failure of the HIH Insurance group. However, finite reinsurance arrangements combined with inappropriate accounting treatment did factor into the masking of the financial challenges of HIH Insurance (IAIS 2012).

\section{London Market Spiral (LMX)}

The Lloyd's of London market expanded during the early 1980s with new individual investors bringing additional capacity to the reinsurance market. This additional capacity led to expanded issuance of excessof-loss contracts to the industry. Important for how the spiral would unfold, some of these risks were again reinsured through retrocession among other Lloyd's syndicates. Opacity within the market resulted in limited understanding of counterparty risks (Carolan et al. 2009). Following a series of catastrophic losses, including the Piper Alpha oil 
platform in the North Sea, losses spiralled among participants through the network of transactions (IAIS 2012; Stanard and Wacek 1991). In some cases, claims were passed back and forth between the same reinsurers. Within the industry, this was defined as a reinsurance spiral. While the claims of the primary insurers were reportedly settled within a relatively short period of time, the reinsured amounts began circulating within the reinsurance sector. In the end, the institution nearly collapsed with many underwriters entering bankruptcy. In 1996, Lloyd's formed Equitas to segregate and run off all pre-1993 Lloyd's liabilities, including those of the spiral (Carolan et al. 2009). Fields, Klein and Myskowski (1998) found support for the interdependency of risk and contagion to the primary insurance industry in the United States from the financial challenges of Lloyd's.

During the LMX spiral period, Lloyd's did not operate with central oversight of underwriting and risk management. With Lloyd's current organizational structure and risk-management processes, a spiral is currently considered highly unlikely within the Lloyd's market. In addition, contractual provisions introduced since then (adjustable pricing and warrants for retaining a portion of the risk) are considered able to mitigate the risk of future spirals (IAIS 2012). However, in the event of a stress event with multiple stressed entities, it is not clear that these contractual terms would necessarily be sufficient to mitigate a spiral.

\section{US Liability Crisis}

Leverage ratios for reinsurers decreased in the early 1980s and then rapidly increased in the middle of the decade when reinsurers experienced large loss development in the early 1980s (Berger, Cummins and Tennyson 1992). As a result, primary insurers experienced significant increases in the cost of reinsurance and reduced capacity as reinsurers exited the market (Berger, Cummins and Tennyson 1992). The US insurance market experienced policy cancellations and withdrawal of insurers from a number of lines of business as primary insurers withdrew underwriting capacity (Winter 1991). Medical malpractice and general liability, including product liability, municipal liability, and directors' and officers' (D\&O) liability, experienced the most material increases in price and reduction in capacity (Winter 1991). The effects were sufficiently widespread to generate real economy impacts in the United States and Canada. Boards of directors experienced a decrease in the participation of outside directors, as fewer companies carrying D\&O insurance and insurance premiums increased (Romano 1989). While most businesses could find coverage, they experienced price increases 
ranging from 43 to 214 per cent (GAO 1988). However, some businesses were either unable to purchase insurance to the desired level or reduced their coverage in response to the price increases (GAO 1988).

More than 90 reinsurance companies were reported to have left the market between 1984 and 1987, including several large European reinsurers (Winter 1991). Governments introduced legislation to facilitate new insurance capacity (GAO 1998) and eventually new capital and capacity entered the market. In Canada, the period from 1984 to 1990 saw the failure of $12 \mathrm{P} \& \mathrm{C}$ insurance companies and, in the late 1990s, alternative insurance mechanisms such as reciprocals were established in response to limitations of underwriting capacity in liability lines of business.

Berger, Cummins and Tennyson (1992) found evidence that disruption in the reinsurance market contributed to and exacerbated the liability crisis in the primary insurance market. A severe supply shock to the primary insurance market was the result of a reduction in reinsurance capacity (Romano 1989; Winter 1991; Berger, Cummins and Tennyson 1992). 


\section{APPENDIX 2: \\ CHARTS DESCRIBING HISTORICAL CATASTROPHE DATA}

FIGURE 13a Global Catastrophe Events, 1980-2013

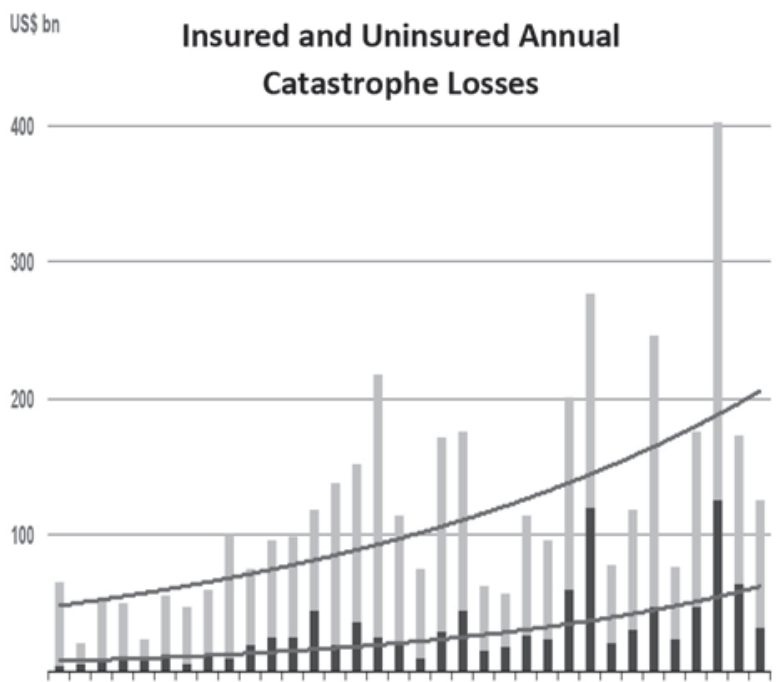

19801982198419861988199019921994199619982000200220042006200820102012

Source: Munich Re NatCat Service

FIGURE 13b Distribution of Loss Event (US\$ billions)

Histogram of Natural Disaster Event Losses

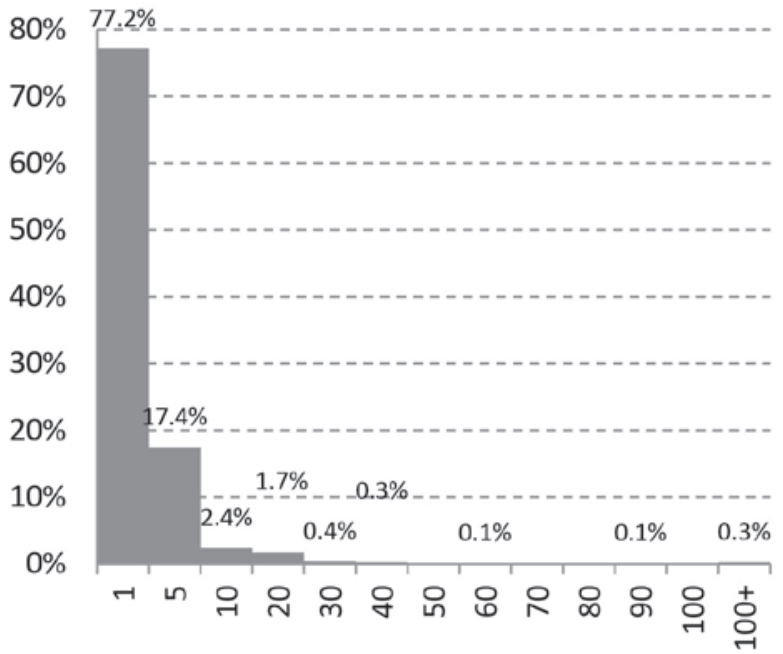

Source: International Disaster Database, Centre for Research on the Epidemiology of Disasters 
FIGURE 14a US Annual Insured Catastrophe Losses (US\$ billion) Collected from Years 1990 to 2012. The biggest recorded insured losses happened in 2005 , the year of Hurricane Katrina.

US Insured Cat Losses

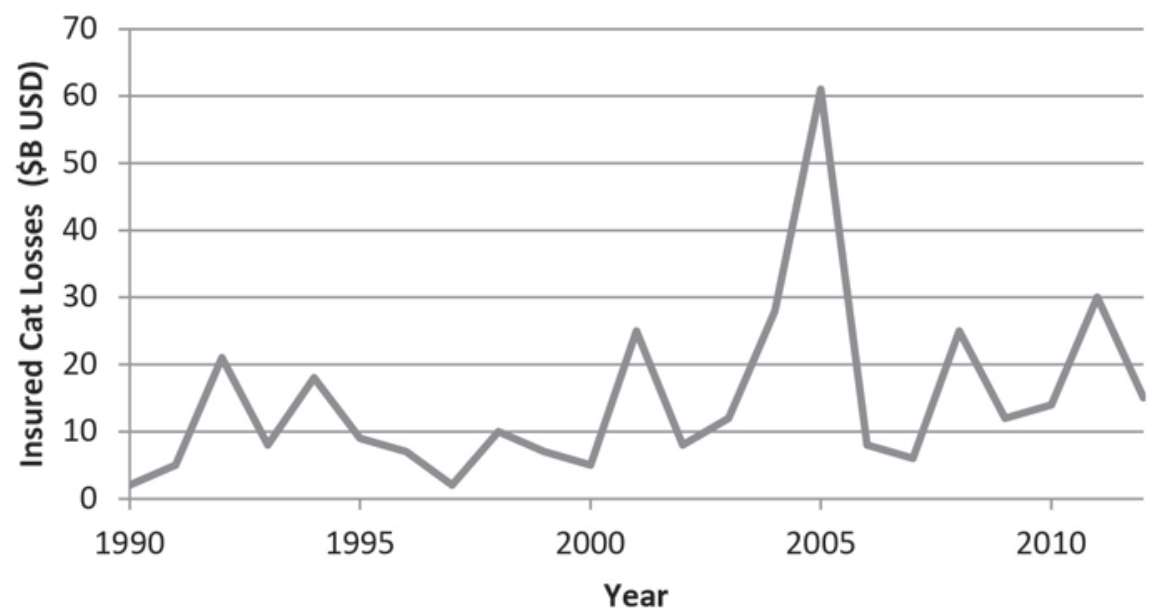

FIGURE 14b Histogram of US Annual Insured Catastrophe Losses. Most of the losses lie in the range US\$5 billion to US\$15 billion.

Insured Loss Histogram

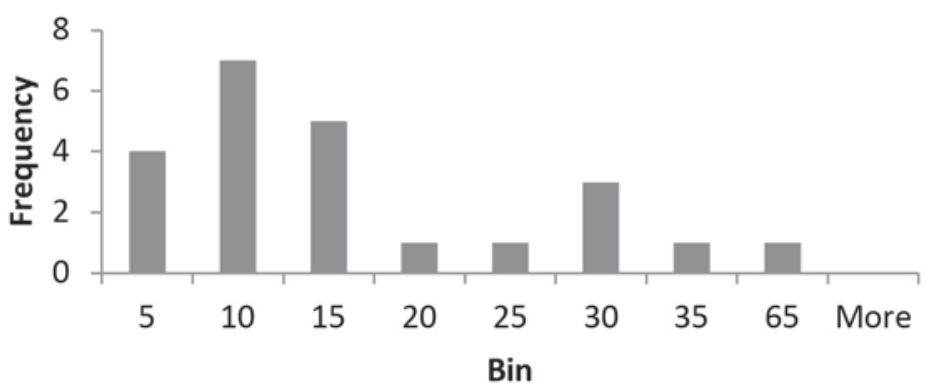




\section{APPENDIX 3: \\ ILLUSTRATION OF REINSURER INTERCONNECTIONS THROUGH RETROCESSION CONTRACTS}

FIGURE 15 Opacity of Reinsurance Market

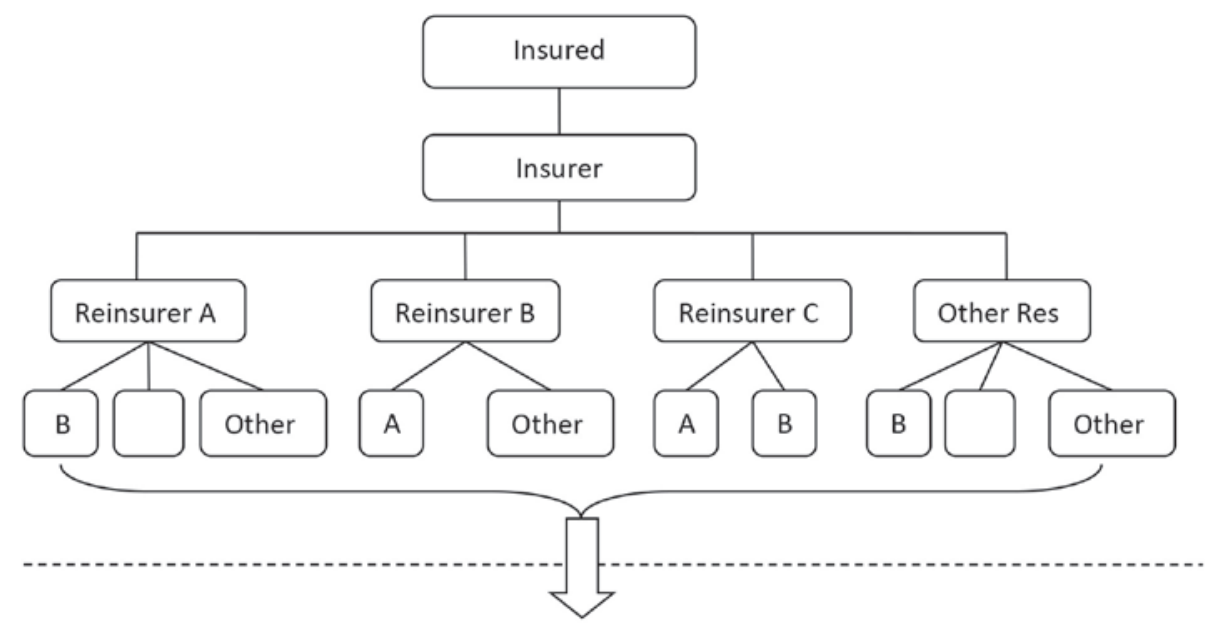

Opaque counterparty arrangements

FIGURE 16 Possible Structure of Counterparty Arrangements Facilitating a Reinsurance Spiral

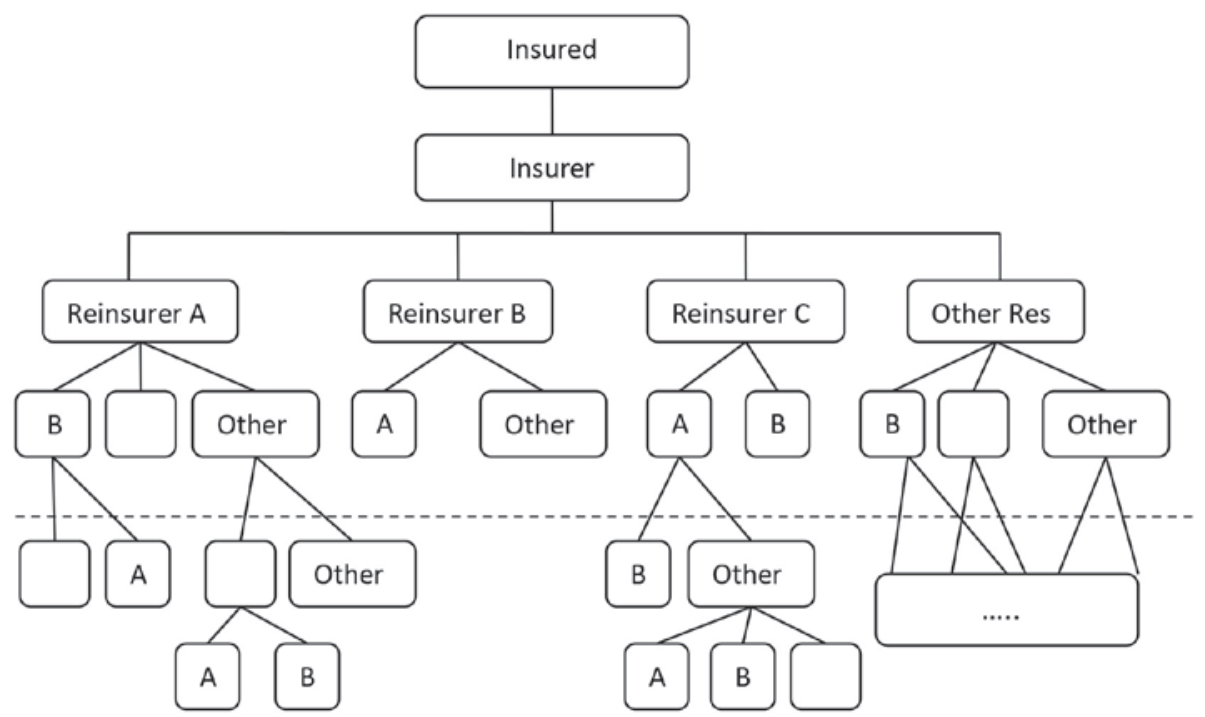

